International Journal of Social Science and Economic Research

ISSN: 2455-8834

Volume:06, Issue:03 "March 2021"

\title{
EFFECT OF EARNINGS QUALITY ON MARKET VALUE OF COMPANIES LISTED AT THE NAIROBI SECURITIES EXCHANGE, KENYA
}

\author{
Arif Mohamed Yusuf ${ }^{1}$ and Dr. Onesmus Mutunga ${ }^{2}$ \\ ${ }^{1}$ School of Business, University Of Nairobi,Kenya \\ ${ }^{2}$ Lecturer, School of Business, University Of Nairobi, Kenya \\ DOI: 10.46609/IJSSER.2021.v06i03.017 URL: https://doi.org/10.46609/IJSSER.2021.v06i03.017
}

\section{ABSTRACT}

This study sought to determine the effect of earnings quality on market value of companies listed at the Nairobi Securities Exchange. A descriptive research design was used. The population of the study comprised of the companies listed at the Nairobi Securities Exchange from 2009 to 2019. A sample of 40 companies was selected using simple random sampling. The study used secondary data obtained from the Nairobi Securities Exchange handbook. Data was summarized using descriptive statistics. Correlation analysis was used to evaluate the relationship between the variables. Multiple linear regression was used to measure effect of accruals quality, earnings persistence, firm size and financial leverage on market value. The study found that market value and accrual quality were weakly positively correlated and the correlation was significant at $5 \%$ level of significance. Market value and earning persistence had a weak positive correlation with the correlation being significant at the 5\% level. Market value and firm size had a weak positive correlation. The correlation was significant at $5 \%$ level. The correlation between market value and financial leverage was positive but weak. The correlation was significant at $5 \%$ level. The result of regression showed that accrual quality had a positive effect on market value of companies listed at the Nairobi Securities Exchange. The effect was significant at the 5\% level of significance. Earnings persistence had a positive effect on market value of companies. The effect was significant at $5 \%$ level of significance. Firm size was found to have a positive effect on market value and was significant at $5 \%$ level of significance. Financial leverage was also found to have a positive effect on market value and the effect was significant at $5 \%$ level of significance. The adjusted coefficient of determination was obtained as $31.2 \%$ indicating that variation in accrual quality, earnings persistence, firm size and financial leverage explained $31.2 \%$ of the variation in market value. The study concluded that high quality accruals have the effect of enhancing the market value of companies listed at the Nairobi Securities Exchange. 


\section{International Journal of Social Science and Economic Research}

ISSN: $2455-8834$

Volume:06, Issue:03 "March 2021"

Persistent earnings also have value enhancing effects for companies listed at the Nairobi Securities Exchange. In addition, the study concluded that larger firms at the Nairobi Securities Exchange have higher market value. Finally, it was concluded that financial leverage has the effect of increasing market value of companies listed at the Nairobi Securities Exchange. The study recommended that since accrual quality, earnings persistence, firm size and financial leverage had value enhancing effects, managers of companies listed at the Nairobi Securities Exchange should focus on improving the quality of accruals and earnings persistence, growing the size of the company and increasing leverage. Also, investors and investments analysts should pay attention to accrual quality, earnings persistence, firm size and financial leverage in evaluating companies for the purpose of investment. Further research may extend to evaluating other measures of earnings quality and consider the limit to financial leverage. Also accrual quality could be measured differently by focusing on operating cash flows.

\section{INTRODUCTION}

\subsection{Background of the Study}

Earnings Quality (EQ)indicates the ability of present period earnings being indicative of expected earnings. If earnings are not expected to reverse in future, they possess superior quality characteristics (Penman \& Zhang, 2002). Schipper and Vincent (2003) explained that superior quality shows how precisely earnings numbers reflect an entity's present operating performance, and is a pointer to future earnings and gives an informative summary for measuring value of the firm. Dechow, Ge and Schrand (2010) views EQ to be the degree that profit reflects true economic earnings. According to Petresen (2010) quality earnings reflect characteristics that enhance the utility of financial information to decision makers relating to relevance, comparability, faithful representation, completeness, verifiability, timeliness and understandability. Teets (2012) noted that, earnings quality is evaluated depending on how well accounting earnings reflect the result relevant in company valuation. Earnings of good quality accurately reflect the present performance, are indicative of prospective performance and offer a useful basis to evaluating firms value (Dechow \& Schrand, 2004).

Three theories inform this study namely; Efficient Market Hypothesis (EMH) by Fama (1970), signaling theory (Spencer, 1973) and theory of agency (Jensen \& Meckling, 1976). EMH is centered on efficiency of markets in processing information. If markets are informationally efficient, the prices of assets traded in those markets reflect relevant information affecting the company's performance in a timely and unbiased manner. Accordingly, historical and expected earnings information is assimilated into security prices and the prices changes in a random manner as new information becomes available. Essentially, the new information reflects the quality of earnings forecast built into security prices based on current earnings. Signaling theory 


\section{International Journal of Social Science and Economic Research}

ISSN: $2455-8834$

Volume:06, Issue:03 "March 2021"

focuses on information imbalances that exist between managers and persons outside the company. Managers by virtue of their position have access to better quality information regarding their company's performance both present and expected. Managers' actions are interpreted as signals by stakeholders on the quality of the company's operations in particular expected earnings and cash flows. Agency theory concerns how managers and shareholders in a corporation relate, with managers being appointed as agents of shareholders. In theory, managers should promote the interest of shareholders if they take actions that maximize shareholders wealth. If managers' compensation is pegged to reported financial performance, it is expected that some earnings manipulation aimed at enhancing executive compensation is likely to occur (Cheng \& Warfield, 2005). In execution of their stewardship responsibility, managers may attempt to engage in activity that generate high EQ that results in maximization of wealth for the shareholders as reflected by the market value of the company.

The Nairobi Securities Exchange (NSE) is the only securities exchange registered in Kenya. The exchange has grown over the decades since its formation in the 1920's where trading took place on the basis of gentleman's agreement; to the open outcry system of the 1990's and is currently automated with the possibility of trading via remote terminals (Ngugi, 2018). There are a total of sixty three companies whose shares are listed and traded at the NSE. The companies are classified into sectors reflecting the characteristics of the economic activity it engages in (NSE, 2019). To facilitate efficient trading and decision making by participants in the exchange, the companies listed are obligated to issue published interim as well as full year financial statements and to make prompt disclosure of any material information that may affect investors decisions (Ngunjiri, 2017). In essence, the financial reports allow investors to evaluate the earning potential of the company. Investors in shares buy the earnings stream of the investee company and are concerned about the company's ability to generate promised earnings. Consequently, market participants are able to gauge a reporting entity's earnings quality in making investment decisions.

\subsubsection{Earnings Quality}

Earnings of high quality are crucial to the financial wellbeing of companies which in turn affects efficiency of financial markets. Investors, investment analysts and regulators rely on the information reported by companies in their financial reports in evaluating financial health the company; this in turn affects the efficient functioning of financial markets. The earnings reported by the company are one of the most anticipated elements of corporate performance (Chan, Jagadeesh \& Lakonishok, 2006). EQ is the level to which earnings announced reflect faithfully an entity's earnings and its utility in predicting future earnings (Bellovary, 2005). Teets (2002) point to a number of factors that affect earnings; decisions by setters of accounting standards, the choices made by the management concerning accounting methods and judgments and managerial 


\section{International Journal of Social Science and Economic Research}

ISSN: $2455-8834$

Volume:06, Issue:03 "March 2021"

estimates for implementing the selected accounting policies. If earnings issued are of high quality, they reflect the underlying economic reality of the entity, if poor quality the effect is to mislead on the company's past and expected performance (Mano, 2018). Users of financial statements should therefore carefully scrutinize the reported numbers to evaluate their relevance and reliability (Choi, 2008).

Dechow et al. (2010) identifies a three case criteria of EQ related to the characteristics of earnings, how investors respond to those earnings and the extent to which earnings are potentially misstated. Characteristics of earnings relate to the qualities embodied in earnings that make them useful to investors for decisions making. The usefulness of reported earnings is characterized by earnings management, earnings smoothing and earnings predictability (Liceran \& Cano, 2017). Investors analyze how accounting earnings are related to stock market returns. Investors' responsiveness to earnings concerns how reported earnings influence equity investors' decisions. Earnings with higher quality are of higher relevance in decision making for the equity investor. Earnings misstatement necessitates revision or restatement of earnings in subsequent periods and indicates issues of concern with EQ (Dechow, et al. 2010).

Several metrics of EQ have been used in research. According to Lyimo (2014) these measures relate to accrual quality, persistence, predictability and evenness of earnings as well as earnings surprise. Accrual quality reflects the difference in reported net earnings and the firms operating cash flows. A large difference indicates poor earnings quality (Anaekenwa \& Rafiu, 2018). Mano (2018) measured accrual quality by dividing operating cash by operating profit. A ratio closer to one indicates higher earnings quality due to the difficulty in manipulating cash flows.

Earnings persistence reflects the sustainability of a firms reported earnings. Persistent earnings are sustainable hence of high quality whereas less persistent ones being transitory and lower quality (Francis, Lafond, Olsson and Schipper, 2004). First order time series regression of earnings is used to measure persistence. The gradient of the regression indicates the persistence of earnings, with a gradient coefficient close to zero indicating lesser persistent earnings (Lyimo, 2014). If reported earnings are predictive of expected earnings, they embody better quality and if they are poor predictor of future earnings they are of poor quality (Penman \& Zhang, 2002). Aguguom and Rafiu (2018) measured predictability on the basis of standard error of the residuals in a time series regression of earnings. Higher standard error indicates poor earnings quality and lower standard error indicating higher earnings quality. Abdelghany (2005) measured earnings quality using a ratio of operating assets to total sales. A large ratio being indicative of low quality of earnings and a small ratio indicating superior quality. In this study, earnings quality will be indicated by accrual quality and earnings persistence.

\subsubsection{Market Value}




\section{International Journal of Social Science and Economic Research}

ISSN: $2455-8834$

Volume:06, Issue:03 "March 2021"

Company's value is the discounted value of future cash flow stream from its operations. When investors buy the stock of a company, they are in essence buying the company's future cash earnings distributable as dividends or realized as capital gains when the shares are sold (Damodaran, 2006). Pinto, Henry, Robinson and Stowe (2013) point to various methods of determining company value. They include the dividend discount model which discounts the forecasted dividend stream, the free cash flows model which discounts the free cash flow to the firm or to equity, and residual valuation model that determines value of company by adjusting opening book value for changes in equity over the period. When applied consistently these approaches result in the same value of the company.

Hitchner (2003) posit that the market value of a company whose stocks are traded in a formal securities exchange is by multiplying price per share with the ordinary shares outstanding. Since market price per share varies constantly, company's market value will also change and can at times be very volatile. Another metric of valuation is Tobin's Q ratio. This ratio approximates the value of firm on the basis of cost of replacing assets. Tobin's $\mathrm{Q}$ divides equity at market value by the book value of net assets(Aguguom \&Rafiu, 2018). Market-to-book (M/B) ratio is yet another commonly used valuation metric. M/B ratio is an aggregate measure of value that captures firm efficiency, growth and risk. It indicates the value placed by the market on the firm's net assets. It also reflects how well the firm's managers are managing the assets to grow the firm (Ceccagnoli, 2009). Marvadi (2015) observe that Tobin's $Q$ and M/B ratio are corresponding metrics of value generated. This study measured market value by multiplying price per share with the ordinary shares outstanding (Hitchner, 2003).

\subsubsection{Earnings Quality and Market Value}

Investors buy into the earnings stream of a company. The current level of earnings is a precursor of what earnings are likely to be in the future and investors use the current earnings in a forwardlooking manner to value an investment (Damodaran, 2006). It is important that the expected earnings of an entity will be realized over time. The current earnings are indicative of expected earnings only if they are of proper quality and reflect the firms operating fundamentals (Zhang, Lan \& Pang, 2013). Firms with less earnings smoothing have superior EQthat enhances the firm's value (Li, Wang \&Xu, 2013).

Gaio and Clara (2011) noted that securities market assign higher valuation for companies with a high EQ which is attributed with better market valuation. The valuation is even higher for firms reporting increased EQ and having greater investment opportunities and frequently raising capital from external markets (Annes, 2016). Choi (2008) aver that holding other factors constant, companies having higher EQ are assigned higher valuation. High EQ entities are rated 


\section{International Journal of Social Science and Economic Research}

ISSN: $2455-8834$

Volume:06, Issue:03 "March 2021"

more favorably in the securities market. Reliable accounting information is thus critical in explaining market value of companies.

\subsubsection{Companies listed at the Nairobi Securities Exchange}

Nairobi Securities Exchange (NSE) is Kenya's only formal registered securities exchange. Its history traces back to 1920's a time in which the exchange facilitated shares dealing on an agreement basis with no trading floor. The exchange was formally registered in 1953. Since then it has undergone several transformations from trading being conducted over a cup of tea to the open outcry system to the current automated trading system that came into operations in the year 2003. Until the year 2014, NSE existed as a private company with membership comprised of registered stock brokers. In 2014 it become a public company through an initial public offering and listed in the same exchange (NSE, 2020).

Currently there are sixty-three companies listed at the NSE divided into various sectors namely; Agricultural, banking, investment, energy and petroleum, construction, insurance, manufacturing, investment services, tele-coms and automobiles, exchange traded funds and real estate investment trust (NSE, 2020). NSE listed firms publish financial statements in accordance to the regulations of the exchange and in compliance with relevant accounting standards (Too, 2015). Among the objectives of the NSE is to ensure investor protection. To achieve this objective the exchange requires listed companies to periodically inform investors in a timely basis and with transparency all material information likely to affect the company performance (Kakiya \&Mugo, 2013).

\subsection{Research Problem}

Investors and markets value high earnings quality more than low earnings quality. However, research findings in this regard are mixed. Yanthani, Aljaso and Dezie (2019) documented that earnings quality and market value of companies listed in Indonesia were significantly positively correlated. Gaio and Clara (2011) using data from 38 countries documented that firm's value and aggregate metrics of EQ had a positive relation. Hung, Thi and Dung's (2020) study in Vietnam indicated positive influence of EQ on firm valuation. Larson and Robert (2014) noted that forward looking measures of EQ were strongly negatively correlated with firms' value for companies listed in USA. Annes and Domingos (2016) documented that for companies listed at the Lisbon stock market, earnings quality and firm valuation had a negative relationship. Aguguom and Rafiu (2018) in a study of Nigerian companies pointed to negative relation of EQ and market value.

Market value of stocks traded at the NSE like those of other securities exchange, fluctuate from time to time. Muiva and Ogilo (2016) noted that these fluctuations are due to the random arrival 


\section{International Journal of Social Science and Economic Research}

ISSN: $2455-8834$

Volume:06, Issue:03 "March 2021"

of information on company fundamentals. Market capitalization of firms traded at NSE was positively related to exchange rate, rate of inflation and GDP (Ndunda et al, 2020). Ouma and Muriu (2014) noted that market value of companies at NSE was affected by factors such as fluctuating exchange rate, changes in money supply and inflation. Oyuga (2014) utilized event study methodology to evaluate how earnings announcement affected share prices at the NSE. The study documented that earnings announcement higher than expected, resulted in a positive adjustment in stock prices while earnings announcement lower than expected, had a downward adjustment in stock prices.

Chepkwony (2018) used accruals to measure earnings smoothing and found earnings smoothness positively influenced stock return for companies at the NSE. Similarly, Ngunjiri (2017) using discretionary accruals posited that earnings management positively affected the performance of NSE listed companies. These studies considered accruals, a measure commonly used to asses quality of earnings, as a measure of earnings management but did not evaluate the quality of those accruals. In light of the reviewed literature and researcher's best knowledge, the researcher finds limited empirical evidence concerning how EQ and firm value are related for NSE companies. More so, international evidence on this subject is mixed. This contributes to the existing literature and possibly resolves the conflict while providing evidence of the subject using data from NSE. It addresses the research question; how does EQ affect market value of companies traded at NSE?

\subsection{Research Objective}

This research sought to determine the effect of earnings quality on market value of companies listed at the Nairobi Securities Exchange.

\subsection{Value of the Study}

Corporate managers will find the result of this research valuable in terms of assessing the effect of EQ on valuation of their entities. It will thus guide the managers to use the power of earnings reporting in the interest of the public. The study will allow investors to evaluate the relevance of reported earnings in making investment decisions. Investors will be able to discern whether the quality of reported earnings can be helpful in predicting future earnings thus guiding optimal resource allocation.

Regulators such as Capital Markets Authority entrusted in ensuring that companies report earnings that reflect the economic reality of companies will obtain useful insights from the research. This will be important for ensuring efficient functioning of capital markets and protection of investors from misleading financial reporting. 
International Journal of Social Science and Economic Research

ISSN: 2455-8834

Volume:06, Issue:03 "March 2021"

The study will contribute to literature in two ways. First, it will evaluate various constructs of earnings quality used in literature in terms of their value relevance in decision making. Secondly, the study contributes to existing empirical evidence on the determinants of market value of companies. The result of the study will form a basis of reference by future researchers with interest in similar lines. The study will also give recommendations for advancing research.

\section{LITERATURE REVIEW}

\subsection{Introduction}

In this chapter extant literature was appraised. Theoretical framework that supports this study was discussed, followed by a discussion of determinants of market value. The chapter also reviewed empirical evidence related to the study, discusses the conceptual framework then concluded by summarizing the literature.

\subsection{Theoretical Framework}

The theoretical foundations for this research revolved around efficient market hypothesis (EMH)by Fama (1970), agency theory (Jensen \& Meckling, 1976) and signaling theory (Spencer, 1973).

\subsubsection{Efficient Market Hypothesis}

EMH is concerned with the ability of markets to impound all relevant information that may affect the company's performance to share price. EMH is concerned with the rapidity and precision of markets in assimilating new information into security prices. Information is considered as anything likely to affect the performance of a company and is unknown or unpredictable. Since information gets to market randomly, share prices also follow a stochastic process. The market is efficient if security prices respond precisely and quickly when new information becomes available. As a result, it is not possible for any investor to intelligently pick stocks that outperform the market on a consistent basis (Fama, 1970). Campanella, Mario \& D'Angelo (2016) assert that market efficiency does not imply that share prices are correct but rather they are unbiased.

Fama (1970) identify three forms of information processing efficiency, namely; weak, semistrong and strong form efficiency. If share prices contain all past information on company performance it embodies weak efficiency. In the semi strong from asset prices incorporate all relevant public information, historical and that which is predictable. Efficiency in the strong form suggests that the market impounds into the security price, all publicly available as well as private information. Damodaran (2006) posited that a strong form encompasses semi-strong form 


\section{International Journal of Social Science and Economic Research}

ISSN: 2455-8834

Volume:06, Issue:03 "March 2021"

while semi strong form encompasses weak efficiency. A semi-strong efficient market possesses earnings information from historical performance and expected performance based on those past earnings. Share prices would then be expected to respond to earnings surprises, which may reflect an assessment of the quality of previous earnings or the inability of historical earnings to estimate expected earnings. While this study did not make an attempt to evaluate the market's ability to interrogate earnings quality, EQ has consequences to market efficiency so that the market is not misled by low quality reporting.

\subsubsection{Agency Theory}

Agency relationships occur when a principal delegates decision making and execution of activities to an agent. The principal expects the agent to act in their interest. In a corporation, shareholders are the principals who appoint managers as their agents and entrust their wealth on them. The shareholders expect that the managers will act in their best interest and maximize their wealth. A conflict arises between shareholders and managers in which managers actions are not in line with those of the shareholders. The conflict occurs due to alignment of incentive and the information asymmetry that exist between shareholders and managers. The principal agent conflict is fueled by incentive mechanisms that are punitive on the agent when performing the activities that attempt to maximize the welfare of the principal (Jensen \& Meckling, 1976).

Agency theory argues that since managers have the discretion in making accounting and reporting decisions, they have the incentive to overstate financial performance especially when their compensation is linked to reported earnings or assets under management. In doing so managers selfishly enhance their utility instead of that of their employers (Marquardt \& Wiedman, 2004). Principals may reduce the excess of agents and lessen the misalignment of interest by incurring agency cost that monitors the actions of the agent. However such monitoring is not perfect and some scope for opportunism will still exist (Hunton, Libby \& Mazza, 2006). If managers' compensation is pegged to reported financial performance, it is expected that some earnings manipulation aimed at enhancing executive compensation is likely to occur (Cheng \& Warfield, 2005). In execution of their stewardship responsibility, managers may attempt to engage in activity that generate high earnings quality that results in maximization of wealth for the shareholders as reflected by the market value of the company.

\subsubsection{Signaling Theory}

Spencer's (1973) seminal work forms the basis of signaling theory. Spencer used the labour market to demonstrate how job applicants engage in behavior that aimed at reducing information asymmetry that hinders employer's selection ability. Prospective employers do not have knowledge concerning the quality of those seeking jobs. Job seekers reduce information 


\section{International Journal of Social Science and Economic Research}

ISSN: $2455-8834$

Volume:06, Issue:03 "March 2021"

asymmetry in the labour market by obtaining education that signals their quality. The signal is deemed effective because low quality candidates are unable to stand the rigor of acquiring education. Stiglitz (2000) posit that presence of information asymmetry affords a necessary situation for efficiency of signaling. Information asymmetry occurs between those with access to information and those could make improved decisions if they had the information. Stiglitz (2002) raises the following issues relating to signaling; quality of the information and intention of signaling. In Spence (2002) quality concerns the signalers ability to satisfy the needs of the entity interpreting the signal while intent concerns the purpose of the signaler.

Signaling theory provides a framework for explaining behavior when two persons do not have access to the same amount and quality of information relating to a subject. The one with information chooses the manner and timing of revealing the information while the recipient chooses how to interpret that information (Malsch, 2013). Position of managers accords them access to information that is not available to outsiders. Such privilege allows managers the opportunity to release information they deem favorable and attempt to minimize information asymmetry between shareholders and the company. Markets rely on earnings reported by managers to forecast the expected performance of the respective companies. Corporate managers may therefore use earnings release to relay information on their company's quality (Rath \& Sun, 2008). The stock market filters the information issued and if it is of reliable quality adjusts stock prices upward, if it is poor quality adjusts stock prices downward (Pham, Chung, Roca \& Bao, 2017). Going by the signaling argument, investors are expected to interpret the action taken by corporate managers to evaluate the expected performance of the company. If such action signals strong expected earnings, demand for the company stock increases resulting in higher stock valuation and vice versa.

\subsection{Determinants of Market Value}

Corporate valuation is an interaction of multiple factors. Several of these factors are discussed hereunder.

\subsubsection{Earnings Quality}

Earnings quality in existing literature is measured using various constructs such as accrual quality, persistence, smoothness and predictability of earnings. Gaio and Clara (2011) posit that earnings of superior quality are rewarded with higher market valuation. Rene and Andson (2016) documented that persistent earnings are associated with lower valuation errors thus improving valuation accuracy.

Earnings persistence measures earnings quality by indicating how sustainable earnings are Schipper and Vincent (2003). Oei, Ramsey and Mather (2008) evaluated persistence of earnings 


\section{International Journal of Social Science and Economic Research}

ISSN: $2455-8834$

Volume:06, Issue:03 "March 2021"

based on the slope coefficient in a regression of earnings time series. Prapaporn (2008) observe that recurrence of earnings symbolizes persistence.

\subsubsection{Firm Revenue}

Pandey (2015) noted that revenue growth influences the firms expected future earnings. Increasing sales may be a worthwhile objective but may not necessarily result in higher market valuation unless such growth results in profit margin that exceed the company's required rate of return (William \& Michael, 2015). Revenue growth potentially enhances market capitalization of a company if operating cost do not grow as much (Chung, 2010). Bogue and Buffa (2014) explained that market capitalization is influenced by revenue growth as well as duration over which that growth is sustainable in excess of capital cost.

Damodaran (2010) pointed to use of revenue for valuation especially with companies with negative earnings so long as the entities are a going concern. Uday and Ro (2008) pointed that initial revenue and earnings announcements are associated with stock price movements. While earnings and revenue are correlated indicators of financial performance, revenue has a marginal informative content in circumstances when earnings are not as signaling. Chanrda et al (2004) explained the pervasiveness of revenue in valuation of firms operating in uncertain and rapidly changing environment because such firms are likely to have volatile earnings. Jegadeesh and Livnat (2006) posit that revenue is more valued for younger firms in emerging industries.

\subsubsection{Firm Size}

Aloke, Gu and Jain (2016) argue that size of listed firm is indicated by its stock market capitalization. Market capitalization is a key metric for investors in evaluating how well their investments are performing. Market capitalization is a well-accepted measure to approximating value of any business entity (Ikikii \& Nzomi, 2013). Sizeis also indicated by the total assets as recorded in a firm's balance sheet. This provides a book-based measure of the size of firm (Liow, 2010).

There is quite some evidence on the how firm size affects firms' value. Chung (2010) show the existence of a size premium in which small firms stocks earn abnormal return over an extended period of time. Davis (2012) using economies of scale argument show that large firm with diversified product lines earn a superior return at lower risk. Atiase (2015) argued that large firms are associated with lower stock price volatility resulting in more stable market valuation. Dewi and Wirajaya (2013) noted that large firms tend to be more profitable, have a wide asset base which when efficiently deployed should result in higher market value for the entity. Yanthani et al (2019) posit that markets value larger firms higher than smaller firms. 
International Journal of Social Science and Economic Research

ISSN: 2455-8834

Volume:06, Issue:03 "March 2021"

\subsubsection{Financial Leverage}

Hamada (1972) showed equity value to be linearly related to debt equity ratio. Usage of leverage increases financial risk for which equity holders require compensation. Thus firms with high leverage need to generate a superior rate of return consistent with that expected by equity holders for the risk they assume. This implies that as debt level increases, the stock prices change at a higher rate to maintain equilibrium valuation in the market. This shows that change in leverage have a direct relationship to volatility of stock prices.

Amato and Burson (2007) point to the constraints associated with usage of debt due to the cost agency. These constraints generate inflexibility in undertaking certain corporate decisions such as sale of unprofitable assets. This may negatively affect the firm's financial performance. Elleuch and Trabelsi (2009) argue that the balance between debt and equity in a firm's statement of financial position influences the firms ROA and ROE. Lee (2012) posits that in a perfect capital market there would be no room for arbitrage and the net worth of an organization is not affected in anyway by leverage.

\subsubsection{Gross Domestic Product}

This indicates the productivity of an economy. It is the monetary value of the output of an economy. It is an overall measure of the total output in an economy (Romer, 2009). Demir (2019) argued that fluctuations in the level of GDP was a major driver of variation in market value of firms at Istanbul exchange. Volatility in GDP was identified as a contributor of unpredictable earnings in an economy which result in volatile stock prices. Kulhanek (2012) hypothesized the existence of a strong connection between economic productivity and stock prices in a given economy. Using data from Central and Eastern Europe, stock prices and GDP growth were shown to have positive long-term relationship and were co-integrated.

Nazir and Nawaz (2010) aver that growth in GDP significantly determined stock market development in Zambia. Share prices increased noticeably in periods when GDP growth was higher than expected. Kaimba (2010) examined the relationship between stock market index and macroeconomic factors. The study documented that GDP growth had an considerable influence on the performance of the stock market. GDP growth was found to result in an appreciation of the NSE-20 share index. Mutulus and Olweny (2018) noted that GDP showed a long-term positive relationship with the stock market index.

\subsubsection{Interest Rate}

Interest rate has been observed to affect the market value of companies in various studies. Udin (2009) in an investigation of how interest rate affected stock prices in developed and developing 


\section{International Journal of Social Science and Economic Research}

ISSN: $2455-8834$

Volume:06, Issue:03 "March 2021"

countries documented that both the level and changes in interest rates adversely affected share prices. Demir (2019) argued that persistently high interest rates are harmful for economies and result in depressed equity prices. Gathogo in a study of macroeconomic factors that influence market capitalization of listed companies at the NSE noted that interest rate on the 90-day treasury bill; interest rates charged by commercial banks as well as Central Bank of Kenya (CBK) base rate significantly negatively affected market capitalization. Ndegwa (2016) researched the macro-economic determinants of stock prices. CBK lending rate and stock prices showed an insignificant positive relationship. Trokon (2014) found no significant causality between interest rate levels and shares values.

\subsubsection{Exchange Rate}

This is price at which a unit of currency is exchanged for bought or sold. Commonly, exchange rate is measured by reference to the amount that a domestic currency is traded against other major currencies such as the USD, Pound Sterling or the Euro (Nshom, 2007). Evidence has indicated some relationship between market value of stocks and rates of exchange. Ibrahim (2003) in a study of the macro-economic determinants of value in Malaysia pointed that equity value was negatively related to rates of exchange. Gathogo (2017) explained that variation on exchange rate was a key determinant of value of companies in Kenya. Weakof Kenya shilling against USD, adversely affected value of shares. However, Ndunda et al (2020) noted that exchange rate variation affected positively the performance of the equity market at NSE.

\subsection{Empirical Evidence}

Gaio and Clara (2011) used a large sample of 7000 companies spread across 38 countries to examine the relation of earning quality and firm value. The study aimed to examine how earnings quality and firms value interacted. Data was analyzed using panel data regression. A meaningful positive association between EQ and firm valuation was determined. The study concluded that firms in weaker legal environment compensate by assuming stricter earnings quality procedures. It also concluded stock markets attaches a higher valuation to strong EQ. it recommended for the strengthening of reporting standards that would result in improvement of quality of reporting.

Choi (2008) examined earnings quality and firm value in the Korean Stock Exchange. The study purposed to examine how indicators of earnings quality interacted with market value of companies. The study sampled the manufacturing firms in the Korean Stock market. It used secondary data covering 2003 to 2005 . Regression methodology was adoptedfor data analysis. The study regressed Tobin's Q ratio against measures of EQ, proxied by accrual, persistence and predictability of earnings. The study attributed higher market valuation to better accrual quality, 


\section{International Journal of Social Science and Economic Research}

ISSN: $2455-8834$

Volume:06, Issue:03 "March 2021"

persistent and predictable earnings other factors held constant. The study recommended that Korean firms should enhance transparency in their earnings reporting so as enhance firms' market value.

Hung, Thi and Dung (2020) investigated how EQ impacted the firms' value in the Vietnamese stock market. The study sought to evaluate how EQ affected valuation. The study controlled for effect of firm size, the rate of investment, financial leverage, dividend payment and revenue growth. An exploratory research design was adopted. Generalized least squares methodology was used to measure effects. The study documented that firm value was significantly positively influenced by EQ. Firm size and dividend were positively connected to valuation. However gearing, revenue growth, book to market value were found to be inversely related to market valuation. It recommended establishment of mechanisms to ensure companies prepare financial statements reflective of fair position of the firm.

Annes and Domingos (2016) studied the relationship between EQ and corporate performance of companies at the Lisbon exchange. It sought to evaluate how market valuation of firms related to the EQ. The study adopted a casual research design. 46 firms listed at Lisbon stock exchange from 1987 to 2016 were sampled. It was found that metrics of EQ namely; accruals quality, earnings predictability and earnings evenness negatively impacted the value of firm. Earnings persistence positively impacted market value. The study concluded that the negative impacts could be the result of earnings manipulations by firms. It was recommended that companies should focus on improving the EQ reported.

Yanthani et al (2019) looked at EQ and market in Indonesia Stock market. An exploratory design and census of firms traded over years 1995-2015 was used. Multiple linear regressions were applied in examining influence of EQ on market value while controlling for dividend payment. EQ and equity value were determined to be negatively correlated. The conclusion was that application of accounting standards and amending of capital markets rules will not by design increase the quality of financial reporting.

Anaekenwa and Rafiu (2018) considered how earnings quality affected value of Nigerian companies. This study set out to examine how EQ affected book value of Nigerian companies. The study purposively sampled 51 listed companies. Secondary data sources were used. Pooled ordinary regression analysis was used for data analysis. Earnings quality was determined to positively impact book value. Book value was documented to be positively influenced by quality of accruals and persistence of earnings. It also found that earnings predictability negatively affected book value. The study recommended analystsshould take into consideration the earnings reliability and accrual accounting. 


\section{International Journal of Social Science and Economic Research}

ISSN: $2455-8834$

Volume:06, Issue:03 "March 2021"

Aguguom, Dada and Nwaobia (2019) examined how earnings persistence was connected to company performance in Nigeria. The research aim was to afford evidence from emerging market on value relevance of earnings persistence. Exploratory factor research approach was utilized. The study sampled 55 companies from Nigeria Stock Exchange between 2008 and 2018. Time series modeling was used to measure earnings persistence. The study documented that earnings persistence affected market value in a non-significant negative manner. It was concluded that earnings persistence was not a reliable predictor of EQ. It recommended caution on analysists when evaluating earnings especially when earnings are unstable as this could have negative and misleading implications for valuation.

Aguguom and Rafiu (2018) evaluated the relationship of EQ and financial performance of Nigerian firms. This research sought to determine the sought to determine how quality of earnings was related to market value. The study sampled 68 Nigerian listed companies. The study used secondary data. Multiple linear regression based on pooled panel data analysis was used. Accrual quality, earnings predictability was found to affect market value negatively. Earnings persistence positively and meaningfully determined value. The study recommended to investors, analysts and policy makers to evaluate the regularity of the times series pattern of earnings.

Ngunjiri (2017) looked into the relation of earnings management and performance of Kenya's listed firms. This study sought to establish if earnings management and financial performance were related. Descriptive research approach was adopted. A census study was carried out. OLS was used for analyzing data. Earnings management was established to have a positive relationship with ROA. Firm sizes, market to book value ratio were also identified as positively influencing performance. A conclusion was made that earnings management positively influenced performance. It was recommended that large firms, and firms with higher market to books value are associated with better financial performance.

Chepkwony (2018) evaluated how earnings management influenced stock returns of NSE quoted companies. It purposed was on investigating how earnings management affected stock performance. Descriptive research design was used. A census of financial companies traded from 2013 to 2017 was carried out. Data was analyzed using multiple linear regression methodology. Stock returns were regressed on discretionary accruals, ratio of market to book and firm size. Earnings management was found to positively affect stock returns with the effect being insignificant. $\mathrm{M} / \mathrm{B}$ ratio and size negatively impacted stock returns. The study concluded that earnings management did not significantly influence stock returns. It was recommended that management of earnings does not help improve the stock returns of a company significantly. 


\section{International Journal of Social Science and Economic Research}

ISSN: 2455-8834

Volume:06, Issue:03 "March 2021"

Gworo's (2019) research focused on relation between earnings volatility and valuation of NSE companies. The aim wasto determine how volatility of earnings affected value. A correlational design was adopted with a sample of 30 companies listed between 2011 and 2015. Secondary data was used. It was determined that earnings volatility positively affected market value of listed companies. Dividend payout indicated a positive effect on the value of companies. Firm with more volatile earnings were documented as having higher market value. It was recommended that managers of listed companies needed to reduce earnings volatility and dividend payout to create positive signals to the stakeholders.

Kakiya, Mugo, Onyuma and Owuor (2013) examined the level of efficiency at the NSE with regard to earnings announcement. The study sought to evaluate how earnings announcement affected efficiency of the stock market. Event study approach was used. Period of the study involved between 2005 and 2011.Earnings announcement had a significant effect on the cumulative average risk adjusted return indicating market inefficiency. The study concluded that the NSE was not semi-strong efficient with regard to earnings announcement. The study recommended to the Capital Markets Authority to issue regulations that minimize inefficiencies in order to enhance investors' confidence.

\subsection{Conceptual Framework}

Ravich and Carl (2016) affirm that conceptual framework generalizes the thinking of the whole research process and may take graphical form or be narrated. The conceptual framework for this research showed the interaction between indicators of earnings quality and market value with size of firm and financial leverage as control variables. 


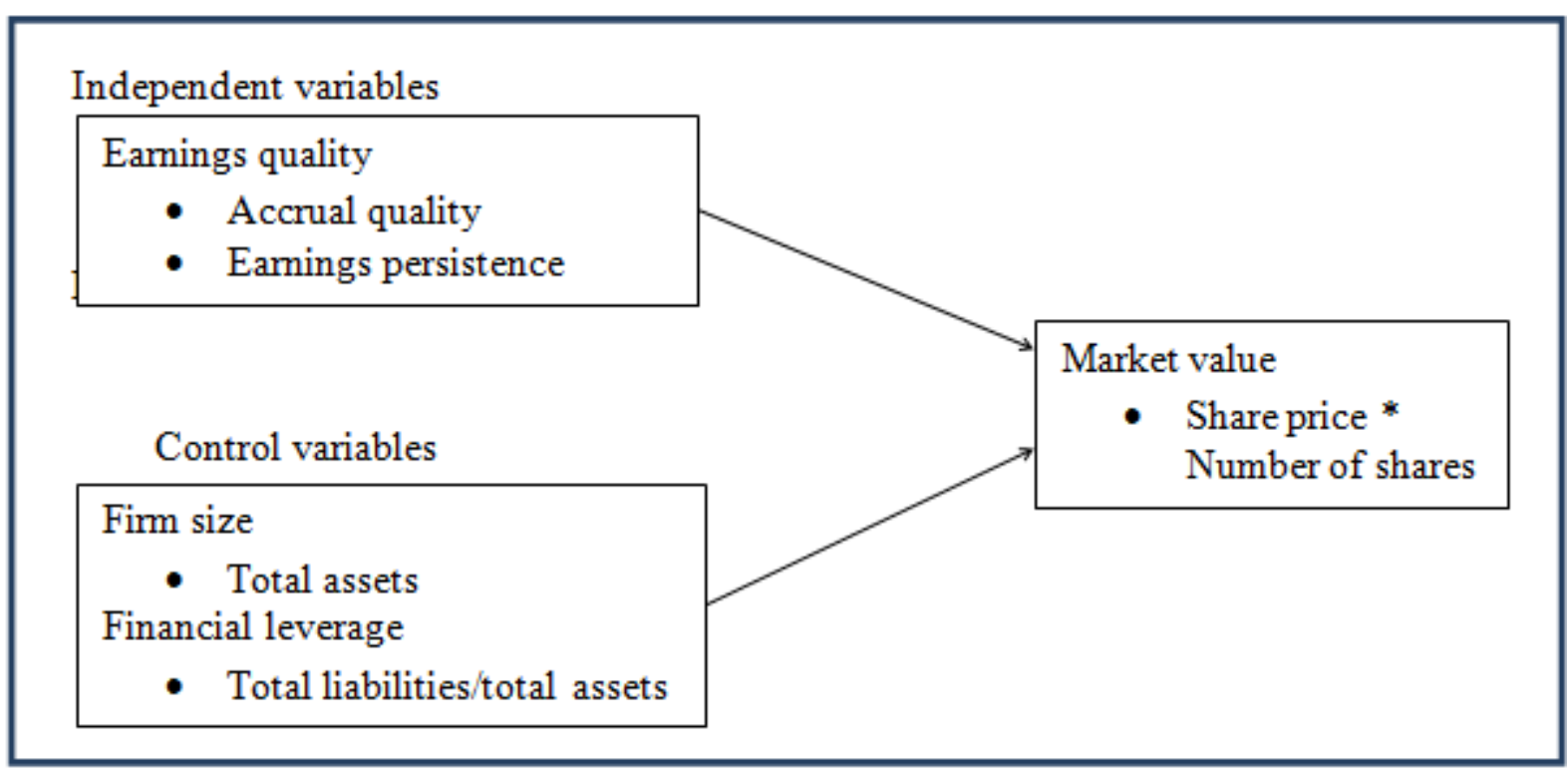

Figure 2.1 Conceptual Framework

Source: Author (2020)

\subsection{Summary of Literature Review and Research Gaps}

Factors that influence market value of companies have been examined extensively. Among the most commonly determinants cited in literature are firm size, leverage, revenue, earnings dividends and earnings quality have mostly been cited as important factors influencing market value of companies. Firm value has variously been represented using books value, M/B ratio or Tobin's Q. Earnings are an important valuation parameter but only if they are of good quality. Sustainability of earnings determines how good quality those earnings are. Various measures of earnings quality used in literature include; accrual quality, persistence, predictability, smoothness, timeliness of earnings.

Various studies have examined how quality of earnings impact valuation of firms. Some of the studies pointing to a positive effect include; Hung et al (2020), Gaio and Clara (2011) and Choi (2008). On the other hand, studies such as Aguguom and Rafiu (2018), Aguguom et al. (2019) and Annes and Domingos (2016) argued that company value was negatively impacted by earnings quality. Locally, the studies of Chepkony (2018) and Ngunjiri (2017) used discretionary accruals to measure earnings management. The studies however did not measure the quality of those accruals. The aforementioned studies provide conflicting evidence as to how EQand value are related. Further, within the scope of the reviewed literature, there is a lack of evidence on the 
International Journal of Social Science and Economic Research

ISSN: 2455-8834

Volume:06, Issue:03 "March 2021"

effect of EQ on market value for companies reporting at the NSE. This study seeks to delve into the controversy by providing additional evidence in this area based on data obtained at the NSE.

\section{RESEARCH METHODOLOGY}

\subsection{Introduction}

The approach adopted for this study is described in this chapter. First, the research designed was outlined followed by a description of the population of interest. Sample selection is then explained, followed by data sources and data collection. The final section explained how the data was analyzed.

\subsection{Research Design}

This specifies process by which data was collected and analyzed. It is based on the research objectives to ensure that data collected is appropriate for answering the research questions (Zikmund, 2003). For this study, descriptive research design was used. This design seeks to provide a description of phenomena related to a subject population. It deals with who, what, when, where and how questions in a topic. It is most useful in helping uncover the relationship between variables and is formalized using clearly stated hypothesis or investigative questions (Cooper \& Schindler, 2011).

Descriptive research design explains features of a population focusing on the 'what' rather than the 'why' of the research subject (Mugenda \& Mugenda, 2008). As stated earlier, this study sought to determine how earnings quality affects market value of companies. To this end, it used descriptive analysis to address the question; how does EQ affect market value of companies at NSE?

\subsection{Target Population}

Population is universe of items possessing features of interest in an analysis (Mugenda \& Mugenda, 2008). The population of interest involved companies traded at NSE between2009 and 2019. Ending 2019, sixty-threecompanies were quoted at NSE. It was anticipated that, the duration provided sufficient data for the research to reach valid conclusions.

\subsection{Sampling and Sample Size}

Sample refers to smaller group of items drawn from a population of interest. Where adequate statistical procedures are followed, a good sample has characteristics similar to the population (Zikmund, 2003). Since the variable of interest is present in each unit of the population, the 
samples were selected using simple random sampling. In this sampling approach each element has the same probability of selection(Cooper \& Schindler, 2011).

Following Cooper and Schindler (2011) the sample size was calculated by:

$n=N\left(c v^{2}\right) /\left\{c v^{2}+(N-1) e^{2}\right.$

Where $\mathrm{n}=$ sample size

$\mathrm{N}=$ target population

$\mathrm{CV}=$ co-efficient of variation which is taken as 0.5

$\mathrm{e}=$ Tolerance at desired level which is taken at 0.05 or at $95 \%$ confidence level

Applying the above formula, the sample was calculated;

$\mathrm{n}=63 *(0.5) 2 /\left\{(0.5)^{2}+(63-1) * 0.05^{2}\right\}$

$\mathrm{n}=63 * 0.25 /\{0.25+(62 * 0.0025)\}$

$\mathrm{n}=16.5 / 0.4125$

$\mathrm{N}=40$, this represent $60 \%$ of the target population.

\subsection{Data Collection}

This research utilized secondary data. This is preexisting data recorded by someone else for other purposes (Kothari, 2004). Secondary data is data in published documents prepared by authors other than the researcher. Data sources used were the published financial reports and the NSE handbook. Data collected included end of year share prices, ordinary shares outstanding, total assets, total liabilities, current liabilities and net income from the year 2009 to 2019.

\subsection{Data Analysis}

Data analysis techniques allow researchers apply logic in understanding data collaborated. It involves determining patterns and summarizing key outcomes obtained from the investigation. It may involve the use simple frequency distribution, bar graph to more complex approaches such as multivariate analysis (Zikmund, 2003). This study made use of frequency distributions, line graphs, descriptive and inferential statistics. Multiple linear regression was utilized to analyze the variables causal effect.

\subsubsection{Analytical Model}


Accrual quality and earnings persistence were regressed on market value with size of firm and leverage used as control variables. The regression model used was specified as:

$\mathrm{MV}=\alpha+\beta_{1} \mathrm{AQ}+\beta_{2} \mathrm{EPer}+\beta_{3}$ Size $+\beta_{4} \mathrm{Lev}+\varepsilon$

Where;

MV =Market value

$\alpha=$ Constant

$\beta \mathrm{i}=$ Coefficient of variable $\mathrm{i}$

$\mathrm{AQ}=$ Accrual quality

EPer=Earnings persistence

Size $=$ Firm size

Lev $=$ Financial leverage

$\varepsilon=$ Error term

\subsubsection{Operationalization of Variables}

The variables used in the regression model are defined as under.

Table 3.1: Operationalization of Variables

\begin{tabular}{|l|l|l|}
\hline Variable & Measure & Reference \\
\hline Market value & Share price * Number of shares & Hitchner (2003) \\
\hline $\begin{array}{l}\text { Accrual } \\
\text { quality }\end{array}$ & $\begin{array}{l}\text { NOAi,t-NOAi,t-1 } \\
\text { NOAi,t-1 } \\
\text { Where NOAi,t }=\text { at time t } \\
\text { NOAi,t-1= Net operating assets of firm i at } \\
\text { time } \mathrm{t}-1\end{array}$ & $\begin{array}{l}\text { Gaio and } \\
(2018)\end{array}$ \\
\hline $\begin{array}{l}\text { Earnings } \\
\text { persistence }\end{array}$ & $\begin{array}{l}\text { The slope coefficient } \beta \text { of the regression; } \\
\text { EPE }=\alpha+\beta E P S_{\mathrm{t}-1}+\varepsilon\end{array}$ & Lyimo (2014) \\
\hline Firm size & Natural logarithm of total assets $^{\text {Nath }}$ & Yanthani et al (2019) \\
\hline
\end{tabular}


International Journal of Social Science and Economic Research

ISSN: 2455-8834

Volume:06, Issue:03 "March 2021"

\begin{tabular}{|l|l|l|}
\hline $\begin{array}{l}\text { Financial } \\
\text { Leverage }\end{array}$ & $\begin{array}{l}\text { Total liabilities } \\
\text { Total assets }\end{array}$ & Hamada (1972) \\
\hline
\end{tabular}

Source: Author (2020)

\subsubsection{Diagnostic Tests}

Diagnostic tests were carried to examine any violation of regression assumptions. The assumptions of linearity, normality of residuals, serial correlation, heteroscedasticity and multicollinearity were tested. Regression analysis presupposes the dependent and independent variables are linearly related. Linearity was tested using the distance from linearity measure. The study tested the hypothesis that there was significant deviation from linearity. Normality was be tested using a histogram and a P-P plot also Shapiro-Wilk test of normality was used (Cook \& Weisberg, 2002).Heteroscedasticity was tested using Beursh-Pagan test (O'Connor, 2000). Serial correlation was checked using Durbin Watson statistic with multicollinearity being tested using variance inflation factor and tolerance limits (Menard, 1995).

\subsubsection{Test of Statistical Significance}

Usefulness of predictor variables was tested t-test at 5\% significance level. Adequacy of the whole regression was tested using F-test. The regression predictive power was determined on the basis of adjusted coefficient of determination.

\section{DATA ANALYSIS, RESULTS AND DISCUSSION}

\subsection{Introduction}

This chapter presented result of data analysis. With a sample of 40 companies over a ten year period, 400 observations were obtained. Diagnostic tests on validity of regression assumptions were first done. Descriptive and correlation analysis were done followed by regression analysis. Finally the findings were discussed.

\subsection{Diagnostic Tests Result}

This section evaluated whether assumptions of regression analysis are violated. The tests covered linearity, normality, heteroscedasticity, serial correlation and multicollinearity.

\subsubsection{Test for Linearity}

Regression analysis presupposes linearity of between variables. Linearity was tested using the distance from linearity measure. The study tested the hypothesis that there was deviation from 
International Journal of Social Science and Economic Research

ISSN: 2455-8834

Volume:06, Issue:03 "March 2021"

linearity. P-value greater than 0.05 for deviation from linearity would result in rejection of the hypothesis.

Table 4.1: Test for Linearity

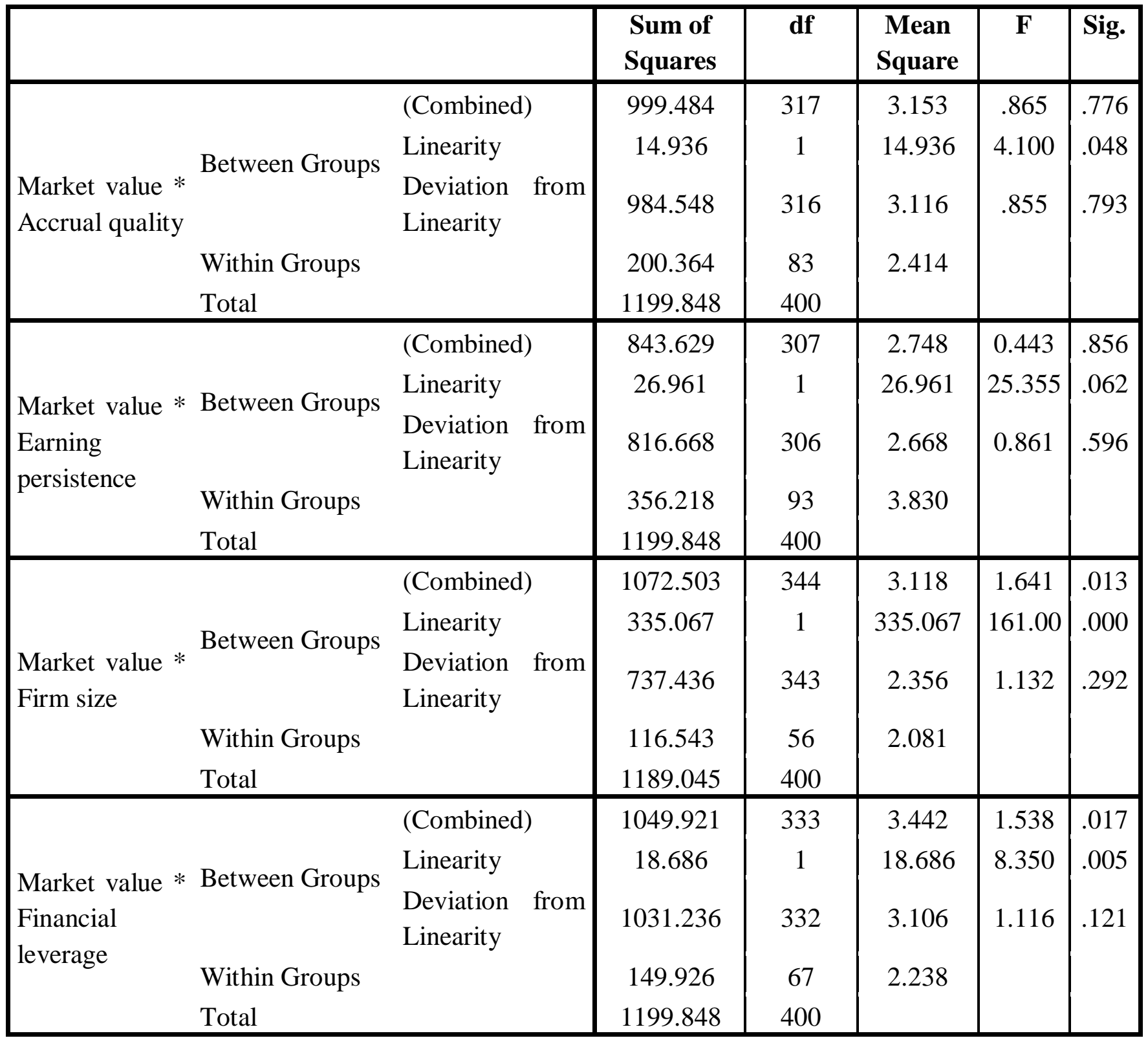

Source: Author (2020)

Results of linearity test are indicated in table 4.1. The p-value for the deviation from linearity between market value and accrual quality was 0.793 . Since $0.793>0.05$, hypothesis of deviation 
from linearity was rejected. The p-value for the linearity test between market value and earnings persistence was 0.596 . This being higher than 0.05 , the hypothesis of deviation from linearity was rejected. Market value and size returned p-value 0.292 , as $0.292>0.05$, hypothesis of deviation from linearity was rejected. Market value and leverage returned a p-value of 0.121 . Because $0.121>0.05$, deviation from linearity assumption was rejected. It was concluded that the variables were linearly related to market value.

\subsubsection{Normality of Residuals}

It is assumed that the residuals follow a normal distribution. To evaluate this assumption, a histogram of residuals and a normal P-P plot were obtained which allowed normality to be evaluated by observation.

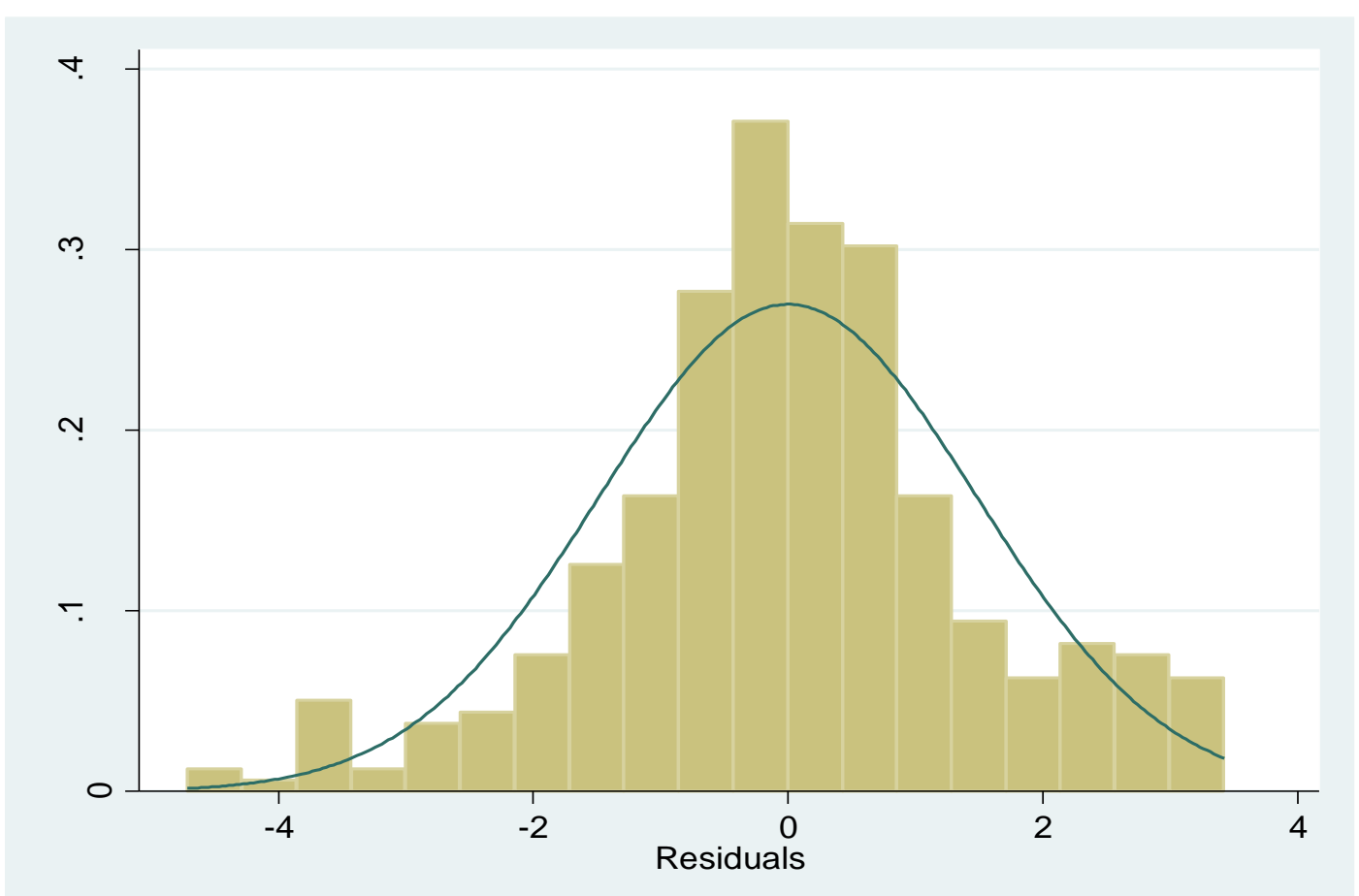

Figure 4.1: Histogram

Source: Author (2020)

Figure 4.1 showed the histogram of residuals. As depicted, the histogram was fairly normally distributed. 


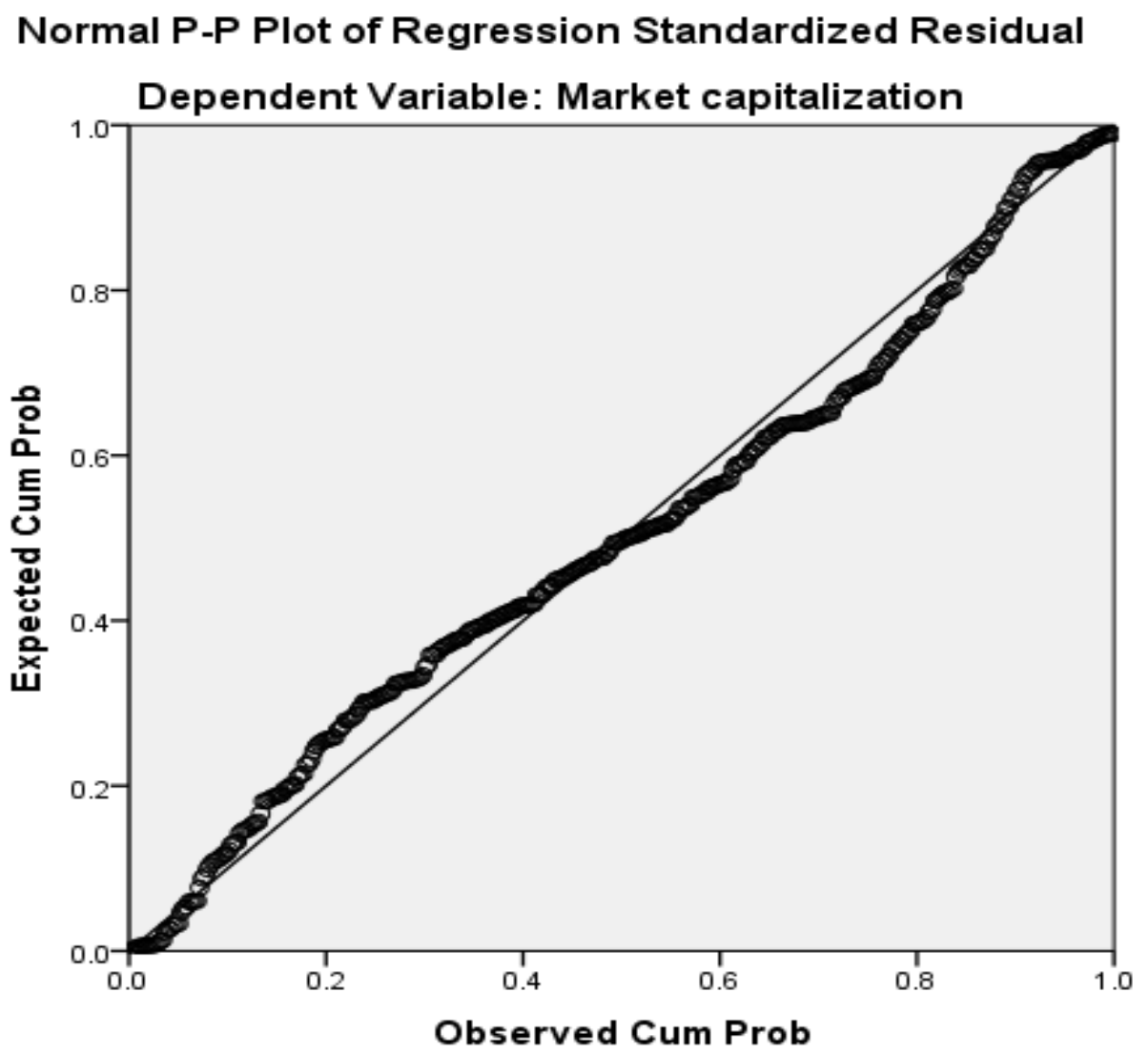

Figure 4.2: Normal P-P Plot

Source: Author (2020)

Figure 4.2 showed the normal P-P plot. The standardized residuals did not deviate much from the 45-degree line. Looking at figure 4.1 and 4.2 suggested that the residuals were fairly normally distributed. To specifically confirm this result, the Shapiro-Wilk test of normality was undertaken. The null hypothesis of normally distributed residuals was taken. A p-value $>0.05$ from this test would result in a failure to reject the null hypothesis.

Table 4.2: Shapiro-Wilk NormalityTest

\begin{tabular}{|l|c|c|c|c|c|}
\hline Variable & Obs & $\mathrm{W}$ & $\mathrm{V}$ & $\mathrm{z}$ & Prob>z \\
\hline $\mathrm{r}$ & 400 & 0.97908 & 1.208 & 0.418 & 0.3562 \\
\hline
\end{tabular}

Source: Author (2020) 
Table 4.2 was the outcome of Shapiro-Wilk normality test. The test indicated that the null hypothesis of normally distributed residuals was not to be rejected as the p-value $0.3562>0.05$. It was therefore inferred that the residuals were normally distributed.

\subsubsection{Test for Heteroscedasticity}

To test the assumption that the error term has a constant variance, Breusch-Pagan test was undertaken. It tests hypothesis that residuals have a constant variance. The hypothesis is rejected for $\mathrm{p}$-value $<0.05$.

\section{Table 4.3: Breusch-Pagan Test}

\begin{tabular}{|l|}
\hline Ho: Constant variance \\
\hline Variables:fitted values of market value \\
\hline Chi2(1) $=0.44$ \\
\hline Prob>chi2 $=0.5068$ \\
\hline
\end{tabular}

Source: Author (2020)

Test result for heteroscedasticity was reported in table 4.3 . Since the p-value $0.5068>0.05$, the hypothesis that the residuals have a constant variance was not rejected.

\subsubsection{Serial Correlation Test}

A further assumption that underlies regression analysis is that the residuals were not serially correlated. This assumption was tested using the Durbin-Watson statistic.

Table 4.4 Durbin-Watson Statistic

\begin{tabular}{|c|c|}
\hline Model & Durbin-Watson \\
\hline & $2.015^{\mathrm{a}}$ \\
\hline
\end{tabular}

Source: Author (2020)

A Durbin-Watson statistic of 2.015 was obtained from table 4.4. Since the statistic was approximately 2 , hypothesis of no serial correlation was supported. This led to the conclusion that the errors were not serially correlated.

\subsubsection{Multicollinearity Test}


Lastly the data was tested for multicollinearity. Independent variables should not be highly correlated otherwise multicollinearity would occur. The null hypothesis of no multicollinearity was tested. If VIF $<10$ and tolerance $>0.2$ multicollinearity was absent.

Table 4.5: Multicollinearity Test

\begin{tabular}{|c|c|c|}
\hline \multirow{2}{*}{ Model } & \multicolumn{2}{|c|}{ Collinearity Statistics } \\
\cline { 2 - 3 } & Tolerance & VIF \\
\hline Accrual quality & .964 & 1.038 \\
Earning persistence & .978 & 1.023 \\
Firm size & .761 & 1.314 \\
Financial leverage & .738 & 1.355 \\
\hline
\end{tabular}

Source: Author (2020)

Table 4.5 depicted that for each variable, the VIF was less than 10 and tolerance higher than 0.2. From this it was concluded that the variables were free from multicollinearity. The analysis above indicated that there were no violations to regression assumptions. It was therefore appropriate to apply the data in a regression analysis.

\subsection{Descriptive Statistics}

To summarize the data, descriptive statistics were computed. These showed the value of the mean and the spread around the mean as indicated by the minimum, maximum and the standard deviation.

Table 4.6: Descriptive Statistics

\begin{tabular}{|l|c|c|c|c|c|}
\hline Model & $\mathbf{N}$ & Minimum & Maximum & Mean & Std. Deviation \\
\hline Market value & 400 & 18.635 & 25.233 & 22.086 & 1.796 \\
Accrual quality & 400 & .011 & .520 & .180 & .155 \\
Earning persistence & 400 & .032 & .851 & .408 & .281 \\
Firm size & 400 & 12.444 & 18.126 & 15.494 & 1.717 \\
Financial leverage & 400 & .000 & .782 & .306 & .266 \\
Valid N (listwise) & 400 & & & & \\
\hline
\end{tabular}

Source: Author (2020) 
Table 4.6 was the derived summary descriptive statistics. Market value averaged 22.086 in natural logarithm terms having a standard deviation of 1.796. Accrual quality averaged 0.180 having standard deviation 0.155. Earnings persistence averaged 0.408 and had a standard deviation of 0.281. Firm size averaged 15.494 having standard deviation 1.717. The financial leverage ratio averaged 0.306 having a standard deviation of 0.266 .

\subsection{Correlation Analysis}

Correlation indicates degree of linear relationship of variables. Karl Pearson measure of correlation was used. The significance of the correlation was evaluated at $5 \%$ level of significance. Hypothesis of no significant correlation between variables was assessed.

Table 4.7 Correlation Matrix

\begin{tabular}{|c|c|c|c|c|c|c|}
\hline & & $\begin{array}{c}\text { Market } \\
\text { value }\end{array}$ & $\begin{array}{l}\text { Accrual } \\
\text { quality }\end{array}$ & $\begin{array}{c}\text { Earnings } \\
\text { persistence }\end{array}$ & Firm size & $\begin{array}{c}\text { Financial } \\
\text { leverage }\end{array}$ \\
\hline \multirow{4}{*}{ Market value } & $\begin{array}{l}\text { Pearson } \\
\text { Correlation }\end{array}$ & 1 & & & & \\
\hline & Sig. (2-tailed) & & & & & \\
\hline & $\mathrm{N}$ & 400 & & & & \\
\hline & Pearson & $.112^{*}$ & 1 & & & \\
\hline \multirow[t]{2}{*}{ Accrual quality } & $\begin{array}{l}\text { Correlation } \\
\text { Sig. (2-tailed) }\end{array}$ & .031 & & & & \\
\hline & $\mathrm{N}$ & 400 & 400 & & & \\
\hline \multirow{3}{*}{$\begin{array}{l}\text { Earning } \\
\text { persistence }\end{array}$} & $\begin{array}{l}\text { Pearson } \\
\text { Correlation }\end{array}$ & $.150^{* *}$ & -.039 & 1 & & \\
\hline & Sig. (2-tailed) & .004 & .447 & & & \\
\hline & $\mathrm{N}$ & 400 & 400 & 400 & & \\
\hline \multirow{3}{*}{ Firm size } & $\begin{array}{l}\text { Pearson } \\
\text { Correlation }\end{array}$ & $.531^{* *}$ & .034 & .078 & 1 & \\
\hline & Sig. (2-tailed) & .000 & .508 & .132 & & \\
\hline & $\mathrm{N}$ & 400 & 400 & 400 & 400 & \\
\hline \multirow{3}{*}{$\begin{array}{l}\text { Financial } \\
\text { leverage }\end{array}$} & $\begin{array}{l}\text { Pearson } \\
\text { Correlation }\end{array}$ & $.125^{*}$ & $.165^{* *}$ & -.068 & $.472^{* *}$ & \\
\hline & Sig. (2-tailed) & .016 & .001 & .191 & .000 & \\
\hline & $\mathrm{N}$ & 400 & 400 & 400 & 400 & 400 \\
\hline
\end{tabular}


International Journal of Social Science and Economic Research

ISSN: 2455-8834

Volume:06, Issue:03 "March 2021"

Source: Author (2020)

Table 4.7 indicated the correlation coefficients between the variables under consideration. Market value and accrual quality had a correlation of 0.112 and p-value of 0.031 . The result established a low positive correlation between market value and EQ. Since $0.031<0.05$, the hypothesis of no significant relationship between market value and earnings quality was rejected in favor of the inference that the correlation was significant. Market value and earnings persistence returned a correlation coefficient of 0.15 and p-value 0.004 . This showed a low positive correlation between market value and earnings persistence. As $0.004<0.05$, the correlation was significant at $5 \%$ level of significance. The correlation between market value and size of the firm was determined at 0.531 having a p-value of 0.000 . Market value and firm size were moderately positively correlated with the relationship being significant as $0.000<0.05$. Lastly, market value and financial leverage showed a correlation of 0.125 with p-value 0.016 . This indicated a weak positive correlation between market value and leverage. The relationship was significant as $0.016<0.05$.

\subsection{Regression Analysis}

To measure the effect of earnings quality on market value of companies listed at the NSE, market value was regressed on two measures of EQ; accrual quality and earnings persistence, and two control variables; firm size and financial leverage were included.

Table 4.8: Model Summary

\begin{tabular}{|l|c|c|c|c|c|}
\hline Model & R & R Square & $\begin{array}{c}\text { Adjusted R } \\
\text { Square }\end{array}$ & $\begin{array}{c}\text { Std. Error of the } \\
\text { Estimate }\end{array}$ & Durbin-Watson \\
\hline & $.565^{\mathrm{a}}$ & .320 & .312 & 1.4866633 & 2.015 \\
\hline
\end{tabular}

Source: Author (2020)

Table 4.8 indicated summary statistics from regression. Adjusted R square was calculated as 0.312 . This meant that variation in explanatory variables explained $31.2 \%$ of the variation in the market value. The remaining $68.8 \%$ of the variability was explained by other factors. The variables; accrual quality, earnings persistence, firm size and financial leverage had a moderate explanatory power on market value. 
International Journal of Social Science and Economic Research

ISSN: 2455-8834

Volume:06, Issue:03 "March 2021"

Table 4.9: Analysis of Variance

\begin{tabular}{|l|c|c|c|c|c|}
\hline Model & Sum of Squares & df & Mean Square & F & Sig. \\
\hline Regression & 380.124 & 4 & 95.031 & 46.176 & $.000^{\mathrm{b}}$ \\
Residual & 808.921 & 393 & 2.058 & & \\
Total & 1189.045 & 397 & & & \\
\hline
\end{tabular}

Source: Author (2020)

In table 4.9 the result of analysis of variance was presented. This result was useful in assessing significance of regression model. It was used in testing whether the independent variables were jointly useful. The result revealed that $F(4,393)=46.176$, with $p=0.000$. Since $p=0.000<0.05$, the independent variables were useful in explaining market value.

Table 4.10: Regression Coefficients

\begin{tabular}{|c|c|c|c|c|c|c|c|}
\hline \multirow[t]{2}{*}{ Model } & \multicolumn{2}{|c|}{$\begin{array}{l}\text { Unstandardized } \\
\text { Coefficients }\end{array}$} & \multirow{2}{*}{\begin{tabular}{|c|}
$\begin{array}{c}\text { Standardized } \\
\text { Coefficients }\end{array}$ \\
Beta
\end{tabular}} & \multirow[t]{2}{*}{$\mathbf{t}$} & \multirow[t]{2}{*}{ Sig. } & \multicolumn{2}{|c|}{$\begin{array}{c}\text { Collinearity } \\
\text { Statistics }\end{array}$} \\
\hline & $\mathbf{B}$ & $\begin{array}{l}\text { Std. } \\
\text { Error }\end{array}$ & & & & Tolerance & VIF \\
\hline$\overline{(\text { Constant })}$ & 12.755 & .762 & & 16.730 & .000 & & \\
\hline Accrual quality & 1.056 & .512 & .091 & 2.064 & .040 & .964 & 1.038 \\
\hline $\begin{array}{l}\text { Earning } \\
\text { persistence }\end{array}$ & .541 & .278 & .085 & 1.998 & .049 & .978 & 1.023 \\
\hline Size & .620 & .052 & .593 & 12.010 & .000 & .761 & 1.314 \\
\hline Leverage & .945 & .339 & .140 & -2.789 & .006 & .738 & 1.355 \\
\hline
\end{tabular}

Source: Author (2020)

Table 4.10 presented the regression coefficients. The regression had a constant of 12.755 with pvalue 0.000 . The constant of 12.755 was the market value of a company whose measure of accrual quality was zero, zero earnings persistence, zero size and zero leverage. The value of the constant was significant as $\mathrm{p}=0.000<0.05$. Accrual quality showed a regression coefficient of 1.056 and $p$-value 0.04 . The slope coefficient for earning persistence was 0.541 with $p$-value of 0.049 . The regression coefficient of firm size was determined as 0.620 and had p-value of 0.000 . Financial leverage regression coefficient was obtained as 0.945 with p-value 0.006 . Final regression equation for the study was: 
International Journal of Social Science and Economic Research

ISSN: 2455-8834

Volume:06, Issue:03 "March 2021"

$\mathrm{MV}=12.755+1.056 \mathrm{AQ}+0.541 \mathrm{EP}+0.620 \mathrm{Size}+0.945 \mathrm{Lev}$

\subsection{Discussion of Findings}

This study purposed to determine how earnings quality affected market value of companies listed at NSE. To this end, two measure of earnings quality; accrual quality and earnings persistence were regressed on market value. It controlled for Firm size and financial leverage. From table 4.10, accrual quality had a coefficient of 1.056 and an associated p-value of 0.04. Thus, accrual quality showed a positive effect on market value. All else the same, a unit increase in accrual quality would result in 1.056 units increase in market value. The increase would be significant as $\mathrm{p}=0.04<0.05$. This concurred with the studies by Aguguom and Rafiu (2018) and Anaekenwa and Rafiu (2018) which indicated that market value was positively influenced by accrual quality for companies listed on Nigerian Stock market. Also, Choi (2008) documented similar findings in the Korean Stock Exchange. The result contradicts Annes and Domingos (2016) which found that accrual quality had a negative influence on market value at the Lisbon Stock Exchange.

The result in table 4.10 showed earnings persistence coefficient 0.541 having p-value 0.049 . Earnings persistence positively affected companies' market value. Holding other factors constant, increasing earnings persistence by one unit increases market value 0.541 units. This effect would be significant given the $\mathrm{p}=0.049<0.05$. This is in concurrence with Choi (2008) that persistent earnings attributed better market value at Korean Stock Exchange. Similar results were documented in Annes and Domingos (2016) at Lisbon Stock Exchange.

Firm size showed coefficient 0.620 having p-value 0.000 as shown in table 4.10. Firm size positively affected market value of companies at NSE. All else remaining constant, increasing firm size by one unit increases market value 0.620 units. Since $p=0.000<0.05$, the effect was significant. This result supports the findings by Hung et al (2002) that size of the firm was positively related to market value.

From table 4.10,financial leverage showed coefficient 0.945 and p-value 0.006. Leverage indicated a positive effect on companies' market value. A unit increase in leverage would be associated with 0.945 units increase in market value all else being constant. The increase would be significant given the $\mathrm{p}=0.006$ is less than 0.05 . The result contradicts those in Hung et al (2002) which found that financial leverage inversely affected value in the Vietnamese market.

\section{SUMMARY, CONCLUSION AND RECOMMENDATIONS}

\subsection{Introduction}




\section{International Journal of Social Science and Economic Research}

ISSN: $2455-8834$

Volume:06, Issue:03 "March 2021"

This chapter summarized major findings of the study, conclusions and recommendations are offered. Limitations of study are also discussed and suggestions for further research.

\subsection{Summary of Findings}

This research aimed at determining how earnings quality affected market value of companies at NSE. Earnings quality was measured using accrual quality and earnings persistence. The study controlled for firm size and financial leverage. Data were summarized using descriptive statistics. Correlation and regression techniques measured relationships. From the descriptive statistics, the mean market value of the sample companies was 22.086 and had a standard deviation of 1.796. Mean measure of accrual quality was 0.180 and had a standard deviation of 0.155. Earning persistence measure averaged 0.408 and had standard deviation of 0.281 . The average firm size was determined as 15.494 with a standard deviation of 1.717. Financial leverage had a mean of 0.306 and a standard deviation of 0.266 .

Correlation analysis indicated that market value and accrual quality were positively correlation, the correlation was weak. The correlation was significant at 5\% level of significance. Market value and earnings persistence showed weak positive relationship, with correlation being significant at 5\% level. Market value and firm size showed a moderate positive correlation which was significant at 5\% level. The correlation between market value and financial leverage was positive but weak. The correlation was also significant at the $5 \%$ level of significance.

Regression analysis revealed that accrual quality positively affected market value of companies at NSE. The effect was significant at the 5\% level. Earnings persistence indicated a positive influence on market value of companies. This effect was significant at 5\% level. Market value was found to be positively influenced by firm size. The influence was significant at $5 \%$ level. Lastly, financial leverage indicated positive influence on companies' market value. The effect was significant at $5 \%$ level.

Analysis of variance indicated that accrual quality, earning persistence, firm size and financial leverage were collectively significant predictors of market value based on 5\% significance level. Adjusted coefficient of determination was 0.312 . The explanatory variables accounted for $31.2 \%$ of the variability in companies' market value at NSE. This indicated a moderate level of explanatory power.

\subsection{Conclusion}

From the findings, it was concluded that enhancing the accrual quality would result in improving the market value of NSE traded companies. Companies with higher quality of accruals obtained better market valuation. The improvement in market value would be economically meaningful. 


\section{International Journal of Social Science and Economic Research}

ISSN: $2455-8834$

Volume:06, Issue:03 "March 2021"

The study also concluded that earnings persistence would increase the market value of companies listed at the NSE. Since the enhancing effects of earnings persistence on market value was significant, it was noted that companies with more persistent earnings would be attributed better market value. Further conclusion was that market value of companies increased significantly with increase in size of firm. Bigger firms would command higher market values relative to smaller ones. In addition, it was concluded that financial leverage increased the market value of companies listed at the NSE. Companies with higher leverage would obtain significantly higher market value.

The study concluded that variability in accrual quality, earnings persistence, firm size and financial leverage explained $31.2 \%$ of the variability in companies' market value at NSE. Thus, the variables had a moderate explanatory power. Also, it was concluded the four variables jointly were significant predictors of companies' market value at NSE.

\subsection{Recommendations}

From findings that accrual quality, earnings persistence, firm size and financial leverage significantly positively affected market value of NSE listed firms, it was recommended that corporate managers entrusted with maximizing shareholders wealth should focus on enhancing the quality of accruals that result from the accounting choices made by the company. By ensuring that accruals in the financial statements are of high quality, the managers would be able to enhance the value that the market attributes to the company. Furthermore, managers should ensure that the earnings of the company are persistent. The study identified that persistent earnings are positively valued by the market. Therefore, by achieving earnings persistence, the company would be able to increase its market value. In addition, the study recommended that managers needed to take actions that profitably increase the amount of total assets used by the company. It is expected that in so doing the market value would increase significantly. Finally, study recommended that corporate managers needed to review the levels of financial leverage of their firms with a view to increase since as identified in this study, financial leverage had the effect of significantly enhancing the market value of companies.

In making investment decisions, investors and investment analysts should recognize the importance of accrual quality in companies for which they are considering investing in. Investors and investment analysts are concerned with selecting investments stocks that enhance the value of their portfolios or those of their clients. The study recommended that investors needed to include in their investments, companies whose accruals quality are considered higher or improving. Considering accrual quality as a factor in valuation may be useful in identify mispricing stocks for either buy or sell decisions. Also, they should focus on companies whose earnings are persistent as those companies are likely to command better valuation in the market. 


\section{International Journal of Social Science and Economic Research}

ISSN: $2455-8834$

Volume:06, Issue:03 "March 2021"

Likewise, earnings persistence may be a useful pointer to market mispricing, which would guide investment decision making. Firm size should also be a key consideration in the investment decision making process as larger firm are likely to be better valued than smaller firms. Finding smaller firms that are highly valued relative to smaller ones in the same industry would be an indicator of potential mispricing.

\subsection{Limitations of the Study}

Two measured of earnings quality related to accrual quality and earnings persistence. Other metrics of earnings quality related to predictability, smoothness and earnings surprise were not factored in. Furthermore, the study did not separate companies with high earnings quality and those with poor earnings quality. Instead the firms were aggregated and the result therefore reflected averages of high and low earnings quality. Also, the study did not attempt to identify the existence of earnings manipulation but rather assumed earnings were fairly calculated and reported. The study measured financial leverage at book value; this measure may not very well capture the effect of financial distress that may occur beyond certain levels of leverage.

\subsection{Suggestions for Further Research}

Only two measures of earnings quality that measured accrual quality, and earnings persistence were relied upon. Further research may consider other measures of earnings quality such as those that focus on earnings predictability, smoothness and surprise. Accrual quality was measured using balance sheet accruals. Further researches may be conducted using measures of accrual quality related to the income statement and operating cash flows. This research can be extended by separating firms into sub-samples of higher earnings quality and lower earnings quality, and examining them separately. While the study indicated a positive effect of financial leverage on market value and recommended an increase on borrowing, borrowing has limit due to financial distress issue. Further studies may consider evaluating limits to borrowing.

\section{ACKNOWLEDGEMENT}

First and foremost, am grateful to God for giving me the ability to complete my research project. Furthermore, the preparation and completion of this project would not have materialized were it not for the assistance from various persons. I am therefore indebted to many who I owe appreciation for their encouragement in conducting this study. Special thanks to Dr. Onesmus Mutunga for supervising and offering guidance that made this project be. Sincere thanks to the lecturers and university colleagues who supported me over the course of this project. 
International Journal of Social Science and Economic Research

ISSN: 2455-8834

Volume:06, Issue:03 "March 2021"

\section{REFERENCES}

Abdelghany, K. (2005). Measuring the quality of earnings. Managerial Auditing Journal, 20(9), 1001-1015.

Aguguom, T. and Rafiu, O. (2018). Earnings quality and firms financial performance: A missing link in the listed firms in Nigeria. International Journal of Accounting \& Finance, 7(2), 32-54.

Ahmad, M. and Abdul, A. (2016). Factors influencing firm value as measured by the Tobin's $Q$ : Empirical evidence from the Saudi Stock Exchange. International Journal of Applied Business and Management, 15(6), 333-360.

Anaekenwa, T. A. and Rafiu, O. S. (2018). Earnings quality and firms book value: An Empirical evidence from the listed firms in Nigeria. Journal of Internet Banking and Commerce, 23(3), $1-22$.

Annes, M.C. and Domingos, I. (2016). The relation between earnings quality and corporate performance for the firms listed in the Lisbon stock exchange.Journal of International Business Studies, 34(1), 5-18.

Adom, D. Hussein, E., and Agyem, J. (2018). Theoretical and conceptual framework: Mandatory ingredients of a quality research. International Journal of Scientific Research, 7(1), 438441.

Atiase, R. K. (1985). Market implication of pre-disclosure information; size and exchange effects. Journal of Accounting Research, 168-176.

Aloke, G., Gu, Z and Jain, P. (2016). Sustained earnings and revenue growth, earnings quality, and earnings response coefficients. International Research Journal of Applied and Basic Sciences, 4 (3), 696-703.

Aguguom, A. T, Dada, S.O, Nwaobia, A. N. (2019). Earnings persistence and firm performance: Implications of analysts' accurate forecast ability from the emerging market of Nigeria. International Journal of Accounting Research, 7(197), 1-8.

Dechow, P. M., Ge, W. and Schrand C. (2010). Understanding earnings quality. A review of the proxies, their determinants and their consequences, Journal of Accounting and Economics, 50 (23), 344-401.

Bogue, M. C. and Buffa, E. (2014). Corporate strategic analysis, New York, The Free Press. 
International Journal of Social Science and Economic Research

ISSN: 2455-8834

Volume:06, Issue:03 "March 2021"

Bellovary, J. L., D. E. Giacomino, and M. D. Akers. (2005). Earnings quality: It's time to measure and report. The CPA Journal, 75 (11), 32-37.

Ceccagnoli, M. (2009). Appropriability, preemption, and firm performance. Strategic Management Journal 30(1), 81-98.

Chandra, U., C. E. Wasley, and G. B. Waymire. (2004). Income conservatism in the U.S. technology sector. Working paper, University of Rochester.

Cheng, Q. and T. D. Warfield. (2005). Equity incentives and earnings management. The Accounting Review, 80, (5), 441-476.

Choi, J. H. (2008). An empirical study on the relationship between earnings quality and firm value. Asia-Pacific Journal of Financial Studies, 37(5), 813-839.

Chung, K. \& Pruitt, S. (1994). A simple approximation of Tobin's Q. Financial Management, 23(3), 70-74.

Chung, R. S. (2010). The effect of the firm's capital structure on the systematic risk of common stocks. The Journal of Finance, 6, (25), 435-443.

Chepkwony, J.C. (2018). Effect of earnings management on stock returns of financial companies listed at the Nairobi Securities Exchange. Unpublished Msc Project, University of Nairobi.

Cooper, R.D. \& Schindler, P.S. (2011).Business research methods. New Delhi: Tata McGraw-Hill.

Cook, R. D., \& Weisberg, S. (2002). Residuals and influence in regression. New York: Chapman $\&$ Hall.

Curwin, J. \& Slater, R. (2008). Quantitative methods for decisions, 6th Edition. South Western: South Western Cengage, Learning.

Chan, C. K., Jegadeesh, N. and Lakonishok, J. (2006) Earnings quality and stock returns. Journal of Business, 79(3) 1041-82.

Campanella, F., Mario, M. and D’Angelo, E. (2016). Efficient market hypothesis and fundamental analysis: An empirical test in the European securities market. Review of Economics and Finance, 1(16), 27-42. 


\section{International Journal of Social Science and Economic Research}

ISSN: 2455-8834

Volume:06, Issue:03 "March 2021"

Davis, A. (2012). The value relevance of revenue for internet firms: Does reporting grossed-up or barter revenue make a difference? Journal of Accounting Research, 40(2), 445-477.

Damodaran, A. (2010). Damodaran on valuation: Security analysis for investment and corporate finance. $2^{\text {nd }}$ Ed. John Wiley\& Sons, Inc. Hoboken, New Jersey.

Dempster, G. (2008). Determining earnings quality: A multi-factor model approach. Journal of the Academy of Business and Economics, 8 (1), 152-156.

Dechow, P., Ge, W. and Schrand, C. (2010). Understanding earnings quality: A review of the proxies, their determinants and their consequences. Journal of Accounting \& Economics, 50 (3), 344-401.

Dechow, P. and C. Schrand (2004), Earnings quality. CFA Journal, 4(12), 1-15.

Demir, C. (2019). Macroeconomic determinants of stock market fluctuations: The case of BIST100. Economies, 7(8), 1-14.

Fama, E. (1970). Efficient capital markets: A review of theory and empirical work. Journal of Finance, 25(12), 383-417.

Francis, J. and Olsson, P. (2006). Earnings quality. Foundation and Trends in Accounting, 1(4), 259-340.

Francis, J, Lafond, R., Olsson, M, P, and Schipper, K. (2004) Cost of capital and earnings attribute. The Accounting Review, 79(4) 969-1010.

Gaio, C. and Raposo, C. (2018) Earnings quality and firm valuation: International evidence. Accounting and Finance, 23(51), 467-499.

Gaio, C. and Clara, R. (2011). Earnings quality and firm valuation, international evidence. Accounting and Finance, 51(2), 467-499.

Grant, C. \& Osanloo, A. (2014). Understanding, selecting, and integrating a theoretical framework in dissertation research: Creating the blueprint for 'house'. Administrative Issues Journal, 5(16), 12-22.

Gworo, C. O. (2019) Earnings volatility and market value of companies listed at the Nairobi Securities Exchange market. TheStrategic Journal of Business and Change Management, 6(1), 17 - 26. 


\section{International Journal of Social Science and Economic Research}

ISSN: $2455-8834$

Volume:06, Issue:03 "March 2021"

Hamada, R. S. (1972). The effect of the firm's capital structure on the systematic risk of common stocks. The Journal of Finance, 6(2), 435-443.

Hitchner, J. R. (2013). Financial valuation: applications and models. John Wiley \& Sons, Inc. Hoboken.

Hitchner, J. R. (2003). Financial valuation: applications and models. John Wiley \& Sons, Inc. Hoboken.

Hung, N, D. Thi, T. and Dung, M. (2020). The impact of earnings quality on firm value: The case of Vietnam. Journal of Asian Finance, Economics and Business, 7(3), 63-72.

Hunton, J. E., R. Libby, and C. L. Mazza. (2006). Financial reporting transparency and earnings management. The Accounting Review, 81(2), 135-157.

Jegadeesh, N., and J. Livnat. 2006. Revenue surprises and stock returns. Journal of Accounting and Economics 41 (12), 147-171.

Jensen, M.C, and Meckling, W.H. (1976). Theory of the firm: managerial behavior, agency costs and ownership structure. Journal of Financial Economics, 15(6),305-360.

Kaimba, A. K. (2010). Relationship between Nairobi Securities Exchange 20 share index and selected macro-economic variables. Unpublished MBA Project, University of Nairobi.

Kakiya, G, Mugo, R., Onyuma, S. and Owuor, G. (2013). Do earnings announcement have an effect on the level of efficiency at the Nairobi Securities Exchange? Research Journal of Finance and Accounting, 14(16), 148-168.

Kalui, F. and Garang, C. (2018). The relationship between earning announcement and stock prices at the Nairobi Securities Exchange. International Journal of Economics, Commerce and Management, 6(5), 166-178.

Kothari, C.R. (2004). Research methodology: methods and techniques, $2^{\text {nd }}$ edition.New Age International, New Delhi.

Kulhanek, L. (2012). The Relationship between stock markets and gross domestic product in the Central and Eastern Europe. International Journal of Business and Management, 4(12), 8-19.

Elleuch, J. \& Trabelsi, L. (2009). Fundamental analysis strategy and the prediction of stock returns. International Research Journal of Finance \& Economics, 30, 95-107. 
International Journal of Social Science and Economic Research

ISSN: 2455-8834

Volume:06, Issue:03 "March 2021"

Gathogo, P. M. (2017). Effect of macroeconomic variables on market capitalization of firms listed at the Nairobi Stock Exchange. European Journal of Business and Social Sciences, 6(6), 182-194.

Larson, C. and Robert, J. (2011). How does earnings quality affect the equity market? An alternative measure and a new perspective. Journal of Financial Intermediation, 13(5), $458-495$.

Lin, F.-L. (2010). A panel threshold model of institutional ownership and firm value in Taiwan. International Research Journal of Finance and Economics, 42(1), 54-62.

Lyimo, G. (2014). Assessing the measures of quality of earnings: evidence from. India. European Journal of Accounting Auditing and Finance Research, 2 (6), 17-28.

Li, J., Wang, F. and Xu, C. (2013). Earnings quality, venture capital and firm value. Computer modeling and new technologies, 17(5), 242-247.

Liceran, G. A. and Cano, R. M. (2017). A review on the multidimensional analysis of earnings quality. EAA Annual Congress, Valencia, 1-28.

Malsch, B. (2013). Politicizing the expertise of the accounting industry in the realm of corporate social responsibility. Accounting, Organizations and Society, 38(2), 149-168.

Marquardt, C. A. and C. I. Wiedman. (2004). How are earnings managed? An examination of specific accruals. Contemporary Accounting Research 21(10), 459-491.

Mano M. (2018). Earnings Quality. Business Perspectives Journal, 2(6), 58-66.

Menard, S. (1995). Applied logistic regression analysis. Sage university paper series on quantitative applications in the social sciences, Thousand Oaks, CA: Sage.

Mugenda, M. O. \& Mugenda A. G. (2008).Research methods: quantitative and qualitative approaches. Nairobi: ACTS Press.

Mutulus, V. and Olweny, T. (2018). The effect of fiscal policy on the performance of the Nairobi Securities Exchange in Kenya. International Journal of Economics, Commerce and Management, 6(6), 294-312.

Nazir, M. and Nawaz, M. (2010). Relationship between economic growth and stock market development. African Journal of Business Management, 4(16), 3473-3479. 


\section{International Journal of Social Science and Economic Research}

ISSN: 2455-8834

Volume:06, Issue:03 "March 2021"

Ndunda, A., King'ori, R. and Ariemba, J. (2020). Effect of macro-economic factors on the performance of the equity market of Nairobi Securities Exchange. International Journal of Business and Commerce, 5(9), 22-33.

Ndegwa, E. N. (2016). The effect of macroeconomic variables on stock market return at the Nairobi Securities Exchange. Unpublished MBA Project, University of Nairobi.

Nelson MW, Skinner DJ. (2013). How should we think about earnings quality? A discussion of earnings quality: Evidence from the field. Journal of Accounting and Economics. 56:3441.

Ngujiri, G. G. (2017). The effect of earnings management on financial performance of quoted companies in Kenya. Unpublished MBA Project University of Nairobi.

Ngugi, N. J. (2018). A historical perspective of the Nairobi Securities Exchange. International Journal of Management, 4(8), 23-28.

Njogu, P.M (2017). Factors influencing stock prices for firms listed at Nairobi securities exchange after initial public offerings in Kenya. Business Management Journal, 22(5), 6-14

Nshom, A. M. (2007). The Association of Exchange rates and Stock returns. International Journal of Economics, Commerce and Management, 4(9), 12-17.

Oei R, Ramsay A, Mather P. (2008). Earnings persistence, accruals and management share ownership. Accounting and Finance. 48:475-502.

O'Connor, B. P. (2000). SPSS and SAS programs for determining the number of components using parallel analysis and Velicer's MAP test. Behavior Research Methods, Instrumentation, and Computers, 32(5), 396-402.

Oyuga, C. N. (2014). Effects of earnings announcement on the share price for firms listed at the Nairobi securities. Unpublished MBA Project, University of Nairobi.

Pandey, I. M., (2015). What drives the shareholder value?.Journal of Accounting and Finance, 1 (14), 105-120.

Petresen, J. (2010). Qualitative characteristics of financial statements. Accounting Journal, 45(9), 8-14.

Penman, S. H. \& Zhang, X. J. (2002). Accounting conservatism, the quality of earnings, 
International Journal of Social Science and Economic Research

ISSN: 2455-8834

Volume:06, Issue:03 "March 2021"

and stock returns. The Accounting Review, 77(2) 237-264.

Pinto, J., Henry, E., Robinson, T. and Stowe, J. (2013). Equity valuation $2^{\text {nd }}$ edition. John Wiley and sons.

Prapaporn K. (2008). The effect of accounting-based earnings attributes on CEO compensation. American Economic Review, 79 (1), 14-31.

Pham, H., Chung, R., Roca, E. and Bao, B. (2017). Discretionary accruals: signaling or earnings management in Australia?. Accounting and Finance, 4(12), 1-31.

Ravitch, S. M. \& Carl, N. M. (2016). Qualitative research: bridging the conceptual, theoretical and methodological. Los Angeles, U.S.A. SAGE Publications, Inc.

Rath, S. \& Sun, L. (2008). The development of earnings management research. International Review of Business Research Papers, 4(2), 265-277.

Rene, C. and AThe role of earnings persistence in valuation accuracy and the time horizon. The Accounting Review, 56(1), 71-86.

Schipper K, Vincent L (2003) Earnings quality. Accounting Horizons, 17(5), 97-110.

Spence, M. 1973. Job market signaling. Quarterly Journal of Economics, 87(5),355-374.

Spence, M. 2002. Signaling in retrospect and the informational structure of markets. American Economic Review, 92(15), 434-459.

Stiglitz, J. E. 2000. The contributions of the economics of information to twentieth century economics. Quarterly Journal of Economics, 115(15), 1441-1478.

Stiglitz, J. E. 2002. Information and the change in the paradigm in economics. American Economic Review, 92(2), 460-501.

Teets, R, W. (2002) Quality of earnings: An introduction to the issue in accounting education. Issue in Accounting Education, 17(1) 335-360.

Tobin. J. (1969). A general equilibrium approach to monetary theory. Journal of Money, Credit, and Banking, 1(1), 15-29.

Too, A. (2015). The effect of publication of financial statements on stock returns of commercial banks listed on the Nairobi Securities Exchange. Unpublished MBA Project, University of Nairobi. 
Trokon, W. (2014). The casual relationship between stock price and interest rates. Unpublished MBA Project, University of Nairobi.

Udin, G.S. (2009). Relationship between Interest Rate and Stock Price: Empirical Evidence from Developed and Developing Countries. International Journal of Business and Management, 4(3), 43-53.

Uday, C. and Ro, B. (2008). The role of revenue in firm valuation. Accounting Horizon, 22(2), 199-222.

William, C. and Michael, E. (2015). The impact of sales and income growth on profitability and market value measures in actual and simulated industries. Developments In Business Simulation \& Experiential Exercises, 22(5), 56-63.

Woolridge, R. and Gray, G. (2003). The new corporate finance capital markets and valuation: an introductory text. Kendall / Hunt Publishing Company.

Yanthani, H., Aljaso, V. and Dezie, W. (2019). Earnings quality and market values of Indonesian listed firms. Australian Accounting Review, 29(1), 95-111.

Zikmund, W.G. (2003). Business research methods. 7th Edition, Thomson/ South-Western.

Zhang B,L. and Pang H. (2013). Empirical study on PE's influence of firm value for small and medium-sized, second board market enterprise-based on Tobin $Q$ value. Macroeconomics, 15(3)15-23.

\section{APPENDICES}

\section{LIST OF ABBREVIATIONS}

CBK: Central Bank of Kenya

DPS: Dividend per Share

EPS: Earnings perShare

EQ: Earnings Quality

GDP: Gross domestic product

IASB: International Accounting Standards Board

IFRS: International Financial Reporting Standards 
M/B: Market-to-Book

NSE: Nairobi Securities Exchange

OLS: Ordinary Least Squares

ROA: Return on Assets

ROE: Return on Equity

VIF: Variance Inflation Factors

Appendix I: Companies Listed at the NSE

\section{AGRICULTURAL \\ 1.Eaagads Ltd Ord \\ 2. Kakuzi Plc Ord. \\ 3.Kapchorua Tea Co. Ltd \\ 4. The Limuru Tea Co. Plc \\ 5. Sasini Plc Ord 1.00 \\ 6. Williamson Tea Kenya Ltd}

BANKING

7.ABSA Bank Kenya Plc

8.BK Group Plc

9.Diamond Trust Bank Kenya Ltd

10.Equity Group Holdings Plc

11.HF Group Plc Ord

12.I\&M Holdings Plc Ord

13.KCB Group Plc Ord

14. National Bank of Kenya Ltd

15.NIC Group Plc

16.Stanbic Holdings Plc

17.Standard Chartered Bank Kenya Ltd

18. The Co-operative Bank of Kenya Ltd

ENERGY \& PETROLEUM

19.KenGen Co. Plc

20.Kenya Power \& Lighting Co Ltd

21.Total Kenya Ltd

22.Umeme Ltd

INSURANCE

23. Britam Holdings Plc

24.CIC Insurance Group Ltd

25.Jubilee Holdings Ltd

\section{INVESTMENT}

32.Centum Investment Co Plc

33. Home Afrika Ltd

34.Kurwitu Ventures Ltd

35. Olympia Capital Holdings ltd

36.Trans-Century Plc

COMMERCIAL AND SERVICES

37.Deacons (East Africa) Plc 38.Eveready

East Africa Ltd

39.Express Kenya Ltd

40.Kenya Airways Ltd

41.Longhorn Publishers Plc

42.Nairobi Business Ventures Ltd

43.Nation Media Group Ltd

44. Sameer Africa Plc

45.Standard Group Plc

46.TPS Eastern Africa Ltd

47.Uchumi Supermarket Plc

48.WPP Scangroup Plc

CONSTRUCTION \& ALLIED

49.ARM Cement Plc

50.Bamburi Cement Ltd

51.Crown Paints Kenya Plc

52.E.A.Cables Ltd

53.E.A.Portland Cement Co. Ltd

\section{MANUFACTURING \& ALLIED}

54.B.O.C Kenya Plc

55.British American Tobacco Kenya Plc

56.Carbacid Investments Ltd 
International Journal of Social Science and Economic Research

ISSN: 2455-8834

Volume:06, Issue:03 "March 2021"

\begin{tabular}{|l|l|}
\hline 26. Kenya Re Insurance Corporation Ltd & 57.East African Breweries Ltd \\
27.Liberty Kenya Holdings Ltd & 58.Flame Tree Group Holdings Ltd \\
28. Sanlam Kenya Plc & 59. Kenya Orchards Ltd \\
& 60.Mumias Sugar Co. Ltd \\
& 61.Unga Group Ltd \\
\hline INVESTMENT SERVICES & EXCHANGE TRADED FUNDS \\
29.Nairobi Securities Exchange Plc & 62.New gold ETF \\
\hline TELECOMMUNICATION & REAL ESTATE INVESTMENT TRUST \\
30.Safaricom Plc & 63.STANLIB FAHARI I-REIT \\
\hline AUTOMOBILES \& ACCESSORIES & \\
31.Car \& General (K) Ltd Ord 5.00 & \\
\hline
\end{tabular}

\section{Appendix II: Raw Data}

\begin{tabular}{|c|c|c|c|c|c|}
\hline No. & Market Value & $\begin{array}{c}\text { Accrual } \\
\text { Quality }\end{array}$ & $\begin{array}{c}\text { Earnings } \\
\text { Persistence }\end{array}$ & Firm Size & $\begin{array}{c}\text { Financial } \\
\text { leverage }\end{array}$ \\
\hline 1 & 18.6351 & 0.042235 & 0.679259 & 15.0882 & 0.186629 \\
\hline 2 & 18.6351 & 0.030717 & 0.679259 & 15.1184 & 0.18894 \\
\hline 3 & 18.6351 & 0.141257 & 0.850478 & 14.6817 & 0.004887 \\
\hline 4 & 18.6351 & 0.136667 & 0.679259 & 15.3519 & 0.172434 \\
\hline 5 & 18.6351 & 0.111095 & 0.679259 & 15.2238 & 0.174368 \\
\hline 6 & 18.6351 & 0.103611 & 0.679259 & 15.4505 & 0.157371 \\
\hline 7 & 18.6351 & 0.520193 & 0.456595 & 16.2243 & 0.613864 \\
\hline 8 & 18.6351 & 0.265157 & 0.456595 & 16.4595 & 0.611149 \\
\hline 9 & 18.6351 & 0.152492 & 0.456595 & 15.0656 & 0.716342 \\
\hline 10 & 18.6351 & 0.520193 & 0.456595 & 15.6977 & 0.602721 \\
\hline 11 & 18.6351 & 0.245 & 0.850478 & 15.3614 & 0.071911 \\
\hline 12 & 18.6351 & 0.520193 & 0.850478 & 15.1423 & 0.050715 \\
\hline 13 & 18.6351 & 0.120483 & 0.850478 & 15.4752 & 0.068102 \\
\hline 14 & 18.6351 & 0.122461 & 0.096356 & 13.1749 & 0.234524 \\
\hline 15 & 18.6351 & 0.520193 & 0.096356 & 13.5041 & 0.781868 \\
\hline 16 & 18.6351 & 0.181172 & 0.314706 & 18.0732 & 0.619976 \\
\hline 17 & 18.6351 & 0.203507 & 0.314706 & 18.1264 & 0.661975 \\
\hline 18 & 18.6351 & 0.01075 & 0.125656 & 14.1705 & 0.084838 \\
\hline 19 & 18.6351 & 0.064931 & 0.20927 & 12.7192 & 0.406536 \\
\hline 20 & 18.7043 & 0.252917 & 0.20927 & 12.4443 & 0.781868 \\
\hline 21 & 18.7282 & 0.01075 & 0.125656 & 14.1711 & 0.088267 \\
\hline 22 & 18.7433 & 0.04423 & 0.20927 & 12.674 & 0.378352 \\
\hline 23 & 18.7433 & 0.520193 & 0.20927 & 12.7864 & 0.565442 \\
\hline
\end{tabular}


International Journal of Social Science and Economic Research

ISSN: 2455-8834

Volume:06, Issue:03 "March 2021"

\begin{tabular}{|c|c|c|c|c|c|}
\hline 24 & 18.8654 & 0.520193 & 0.125656 & 13.8806 & 0.518846 \\
\hline 25 & 18.8864 & 0.016958 & 0.20927 & 12.7522 & 0.652155 \\
\hline 26 & 18.8864 & 0.233072 & 0.20927 & 12.4869 & 0.781868 \\
\hline 27 & 18.963 & 0.01075 & 0.125656 & 14.1738 & 0.142866 \\
\hline 28 & 19.0085 & 0.520193 & 0.620688 & 14.4356 & 0.172204 \\
\hline 29 & 19.2541 & 0.100019 & 0.20927 & 12.7693 & 0.487141 \\
\hline 30 & 19.337 & 0.01075 & 0.125656 & 12.4443 & 0.10532 \\
\hline 31 & 19.3968 & 0.111912 & 0.620688 & 14.8228 & 0.02933 \\
\hline 32 & 19.3968 & 0.324603 & 0.620688 & 14.7167 & 0.074463 \\
\hline 33 & 19.3991 & 0.111921 & 0.300136 & 13.776 & 0.282937 \\
\hline 34 & 19.4365 & 0.025684 & 0.20927 & 13.5693 & 0.508336 \\
\hline 35 & 19.4503 & 0.01075 & 0.125656 & 12.4443 & 0.10532 \\
\hline 36 & 19.468 & 0.01075 & 0.20927 & 13.5953 & 0.485954 \\
\hline 37 & 19.4834 & 0.01075 & 0.116833 & 12.4443 & 0.233835 \\
\hline 38 & 19.5069 & 0.319759 & 0.096356 & 12.7896 & 0.220586 \\
\hline 39 & 19.7016 & 0.423857 & 0.274364 & 12.4443 & 0.17283 \\
\hline 40 & 19.7016 & 0.520193 & 0.274364 & 12.4443 & 0.188853 \\
\hline 41 & 19.7687 & 0.520193 & 0.147475 & & 0 \\
\hline 42 & 19.7687 & 0.520193 & 0.147475 & & 0 \\
\hline 43 & 19.7907 & 0.269147 & 0.096356 & 13.028 & 0.231833 \\
\hline 44 & 19.812 & 0.262703 & 0.274364 & 12.4443 & 0.194046 \\
\hline 45 & 19.8304 & 0.323604 & 0.096356 & 13.1132 & 0.781868 \\
\hline 46 & 19.8354 & 0.43606 & 0.582757 & 14.4379 & 0.187388 \\
\hline 47 & 19.8976 & 0.520193 & 0.620688 & 12.4443 & 0 \\
\hline 48 & 19.9245 & 0.194226 & 0.300136 & 14.0749 & 0.246671 \\
\hline 49 & 19.9265 & 0.01168 & 0.679259 & 15.0468 & 0.200252 \\
\hline 50 & 19.9318 & 0.132768 & 0.850478 & 14.8403 & 0.227451 \\
\hline 51 & 19.9318 & 0.336782 & 0.850478 & 14.7156 & 0.218171 \\
\hline 52 & 19.9318 & 0.195679 & 0.850478 & 14.4254 & 0.150011 \\
\hline 53 & 19.9318 & 0.138928 & 0.850478 & 14.2466 & 0.143959 \\
\hline 54 & 19.9753 & 0.16194 & 0.300136 & 14.225 & 0.247255 \\
\hline 55 & 19.9955 & 0.127107 & 0.096356 & 13.2328 & 0.781868 \\
\hline 56 & 20.0025 & 0.166026 & 0.295788 & 13.9495 & 0.079533 \\
\hline 57 & 20.0471 & 0.034022 & 0.300136 & 14.4408 & 0.236043 \\
\hline 58 & 20.0616 & 0.520193 & 0.274364 & 12.6427 & 0.217305 \\
\hline 59 & 20.0995 & 0.200069 & 0.300136 & 14.4073 & 0.236065 \\
\hline
\end{tabular}


International Journal of Social Science and Economic Research

ISSN: 2455-8834

Volume:06, Issue:03 "March 2021"

\begin{tabular}{|c|c|c|c|c|c|}
\hline 60 & 20.1194 & 0.520193 & 0.116833 & 13.2513 & 0.153609 \\
\hline 61 & 20.1412 & 0.340832 & 0.116833 & 12.7376 & 0.217658 \\
\hline 62 & 20.1559 & 0.094102 & 0.096356 & 13.1179 & 0.204635 \\
\hline 63 & 20.1632 & 0.129093 & 0.300136 & 13.8974 & 0.245627 \\
\hline 64 & 20.201 & 0.018355 & 0.295788 & 13.7481 & 0.104685 \\
\hline 65 & 20.2177 & 0.144778 & 0.591875 & 12.4443 & 0.089864 \\
\hline 66 & 20.2422 & 0.133808 & 0.300136 & 14.5664 & 0.224845 \\
\hline 67 & 20.2422 & 0.172479 & 0.300136 & 14.5638 & 0.209055 \\
\hline 68 & 20.2422 & 0.149284 & 0.300136 & 14.4047 & 0.214719 \\
\hline 69 & 20.7511395 & 0.069163095 & 0.229438485 & 15.204846 & 0.09600162 \\
\hline 70 & 20.756667 & 0.28440294 & 0.117417165 & 12.9832935 & 0.116806125 \\
\hline 71 & 20.7794805 & 0.08654256 & 0.229438485 & 15.3832335 & 0.10250397 \\
\hline 72 & 20.8327455 & 0.0361599 & 0.09683778 & 13.124697 & 0.1601166 \\
\hline 73 & 20.835258 & 0.070495725 & 0.29726694 & 14.0873865 & 0.0388935 \\
\hline 74 & 20.859579 & 0.46067391 & 0.14697723 & 12.927516 & 0 \\
\hline 75 & 20.8634985 & 0.522793965 & 0.117417165 & 13.5026775 & 0.04293963 \\
\hline 76 & 20.0261325 & 0.0117384 & 0.682655295 & 15.122034 & 0.20125326 \\
\hline 77 & 20.031459 & 0.13343184 & 0.85473039 & 14.9145015 & 0.228588255 \\
\hline 78 & 20.031459 & 0.33846591 & 0.85473039 & 14.789178 & 0.219261855 \\
\hline 79 & 20.031459 & 0.196657395 & 0.85473039 & 14.497527 & 0.150761055 \\
\hline 80 & 20.031459 & 0.13962264 & 0.85473039 & 14.317833 & 0.144678795 \\
\hline 81 & 20.0751765 & 0.1627497 & 0.30163668 & 14.296125 & 0.248491275 \\
\hline 82 & 20.0954775 & 0.127742535 & 0.09683778 & 13.298964 & 0.78577734 \\
\hline 83 & 20.2489 & 0.22267 & 0.679259 & 15.0586 & 0.164968 \\
\hline 84 & 20.3066 & 0.020806 & 0.116833 & 13.7016 & 0.085366 \\
\hline 85 & 20.3772 & 0.083388 & 0.116833 & 13.5156 & 0.066022 \\
\hline 86 & 20.3772 & 0.23008 & 0.116833 & 13.7226 & 0.066626 \\
\hline 87 & 20.3927 & 0.125023 & 0.850478 & 14.9581 & 0.201175 \\
\hline 88 & 20.445 & 0.099473 & 0.228297 & 15.2241 & 0.084387 \\
\hline 89 & 20.445 & 0.078217 & 0.228297 & 15.0627 & 0.096003 \\
\hline 90 & 20.4573 & 0.281278 & 0.096356 & 12.7876 & 0.389366 \\
\hline 91 & 20.474 & 0.016961 & 0.140314 & 14.4431 & 0.018772 \\
\hline 92 & 20.474 & 0.520193 & 0.140314 & 14.4262 & 0.003573 \\
\hline 93 & 20.4879 & 0.396796 & 0.147475 & 18.1264 & 0.781868 \\
\hline 94 & 20.5656 & 0.048944 & 0.295788 & 13.7959 & 0.079762 \\
\hline 95 & 20.575 & 0.121726 & 0.850478 & 15.3338 & 0.264329 \\
\hline
\end{tabular}


International Journal of Social Science and Economic Research

ISSN: 2455-8834

Volume:06, Issue:03 "March 2021"

\begin{tabular}{|c|c|c|c|c|c|}
\hline 96 & 20.6479 & 0.068819 & 0.228297 & 15.1292 & 0.095524 \\
\hline 97 & 20.6534 & 0.282988 & 0.116833 & 12.9187 & 0.116225 \\
\hline 98 & 20.6761 & 0.086112 & 0.228297 & 15.3067 & 0.101994 \\
\hline 99 & 20.7178 & 0.136134 & 0.146246 & 12.6843 & 0.07104 \\
\hline 100 & 20.7178 & 0.356875 & 0.146246 & 12.4859 & 0 \\
\hline 101 & 20.7178 & 0.043607 & 0.146246 & 12.5567 & 0 \\
\hline 102 & 20.7178 & 0.275133 & 0.146246 & 12.9273 & 0.023335 \\
\hline 103 & 20.7265 & 0.125572 & 0.146246 & 12.9815 & 0 \\
\hline 104 & 20.7291 & 0.03598 & 0.096356 & 13.0594 & 0.15932 \\
\hline 105 & 20.7316 & 0.070145 & 0.295788 & 14.0173 & 0.0387 \\
\hline 106 & 20.7558 & 0.458382 & 0.146246 & 12.8632 & 0 \\
\hline 107 & 20.7597 & 0.520193 & 0.116833 & 13.4355 & 0.042726 \\
\hline 108 & 20.7661 & 0.520193 & 0.140314 & 18.1264 & $4.60 \mathrm{E}-06$ \\
\hline 109 & 20.78 & 0.520193 & 0.620688 & 12.4443 & 0 \\
\hline 110 & 20.8653 & 0.034197 & 0.140314 & 14.66 & 0 \\
\hline 111 & 20.8743 & 0.019217 & 0.850478 & 15.2189 & 0.20409 \\
\hline 112 & 20.9056 & 0.126844 & 0.274364 & 12.4443 & 0.156319 \\
\hline 113 & 20.9241 & 0.059523 & 0.218455 & 18.0052 & 0.781868 \\
\hline 114 & 20.9306 & 0.037657 & 0.140314 & 14.6263 & 0 \\
\hline 115 & 20.945 & 0.086048 & 0.218455 & 18.0878 & 0.781868 \\
\hline 116 & 20.9754 & 0.520193 & 0.218455 & 17.9474 & 0.781868 \\
\hline 117 & 21.0223 & 0.048536 & 0.031539 & 14.8062 & 0.229086 \\
\hline 118 & 21.0324 & 0.091617 & 0.679259 & 14.7157 & 0.288361 \\
\hline 119 & 21.0408 & 0.520193 & 0.147475 & 18.1264 & 0.595528 \\
\hline 120 & 21.0423 & 0.01075 & 0.146246 & 13.7597 & 0 \\
\hline 121 & 21.045 & 0.273665 & 0.77109 & 13.992 & 0.388386 \\
\hline 122 & 21.0452 & 0.179607 & 0.157464 & 15.8425 & 0.254128 \\
\hline 123 & 21.0581 & 0.068835 & 0.140314 & 14.6408 & 0 \\
\hline 124 & 21.0704 & 0.191192 & 0.77109 & 14.3301 & 0.395545 \\
\hline 125 & 21.0707 & 0.458381 & 0.218455 & 17.3342 & 0.781868 \\
\hline 126 & 21.0834 & 0.217131 & 0.140314 & 14.8565 & 0.053784 \\
\hline 127 & 21.146004 & 0.522793965 & 0.148212375 & 18.217032 & 0.59850564 \\
\hline 128 & 21.1475115 & 0.01080375 & 0.14697723 & 13.8284985 & 0 \\
\hline 129 & 21.150225 & 0.275033325 & 0.77494545 & 14.06196 & 0.39032793 \\
\hline 130 & 21.150426 & 0.180505035 & 0.15825132 & 15.9217125 & 0.25539864 \\
\hline 131 & 21.405093 & 0.028231455 & 0.031696695 & 14.757219 & 0.229416375 \\
\hline
\end{tabular}


International Journal of Social Science and Economic Research

ISSN: 2455-8834

Volume:06, Issue:03 "March 2021"

\begin{tabular}{|c|c|c|c|c|c|}
\hline 132 & 21.406098 & 0.125738565 & 0.29726694 & 14.205876 & 0.010893195 \\
\hline 133 & 21.412932 & 0.124819995 & 0.14697723 & 12.9131445 & 0 \\
\hline 134 & 21.4482075 & 0.021027615 & 0.031696695 & 14.7293805 & 0.287776725 \\
\hline 135 & 21.1916 & 0.152356 & 0.679259 & 14.8575 & 0.220257 \\
\hline 136 & 21.1939 & 0.014385 & 0.541298 & 14.3399 & 0 \\
\hline 137 & 21.1958 & 0.01075 & 0.850478 & 15.1999 & 0.243249 \\
\hline 138 & 21.2056 & 0.22034 & 0.582757 & 15.4917 & 0.200945 \\
\hline 139 & 21.231 & 0.033672 & 0.287437 & 16.2849 & 0.590423 \\
\hline 140 & 21.2361 & 0.039736 & 0.140314 & 14.8159 & 0.067277 \\
\hline 141 & 21.2438 & 0.520193 & 0.093681 & 15.7713 & 0.781868 \\
\hline 142 & 21.2741 & 0.425113 & 0.314706 & 18.1264 & 0.673138 \\
\hline 143 & 21.2986 & 0.028091 & 0.031539 & 14.6838 & 0.228275 \\
\hline 144 & 21.2996 & 0.125113 & 0.295788 & 14.1352 & 0.010839 \\
\hline 145 & 21.3064 & 0.124199 & 0.146246 & 12.8489 & 0 \\
\hline 146 & 21.3415 & 0.020923 & 0.031539 & 14.6561 & 0.286345 \\
\hline 147 & 21.3571 & 0.263979 & 0.850478 & 15.1923 & 0.285173 \\
\hline 148 & 21.3717 & 0.520193 & 0.093681 & 16.5865 & 0.526766 \\
\hline 149 & 21.3834 & 0.520193 & 0.582757 & 15.2926 & 0.207691 \\
\hline 150 & 21.3874 & 0.079748 & 0.541298 & 14.1983 & 0.007843 \\
\hline 151 & 21.3918 & 0.10696 & 0.314706 & 18.1264 & 0.675606 \\
\hline 152 & 21.3924 & 0.160578 & 0.541298 & 14.1215 & 0.021695 \\
\hline 153 & 21.4093 & 0.445499 & 0.147475 & 18.1264 & 0.712802 \\
\hline 154 & 21.4122 & 0.018934 & 0.541298 & 14.3544 & 0 \\
\hline 155 & 21.4234 & 0.164756 & 0.582757 & 15.6442 & 0.205744 \\
\hline 156 & 21.4254 & 0.078923 & 0.031539 & 16.2591 & 0.781868 \\
\hline 157 & 21.4601 & 0.046229 & 0.541298 & 14.2926 & 0.000164 \\
\hline 158 & 21.4693 & 0.520193 & 0.146246 & 13.7617 & 0 \\
\hline 159 & 21.477 & 0.139441 & 0.031539 & 14.8143 & 0.252924 \\
\hline 160 & 21.4933 & 0.260314 & 0.031539 & 15.8542 & 0.781868 \\
\hline 161 & 21.5038 & 0.05013 & 0.140314 & 14.5894 & 0 \\
\hline 162 & 21.5511 & 0.107836 & 0.031539 & 14.7588 & 0.268963 \\
\hline 163 & 21.609 & 0.231842 & 0.850478 & 13.6586 & 0.056805 \\
\hline 164 & 21.6155 & 0.424719 & 0.541298 & 14.5522 & 0.006233 \\
\hline 165 & 21.6155 & 0.163658 & 0.541298 & 14.3735 & 0 \\
\hline 166 & 21.6384 & 0.06096 & 0.157464 & 15.9363 & 0.229155 \\
\hline 167 & 21.67 & 0.01075 & 0.541298 & 14.2966 & 0.059594 \\
\hline
\end{tabular}


International Journal of Social Science and Economic Research

ISSN: 2455-8834

Volume:06, Issue:03 "March 2021"

\begin{tabular}{|c|c|c|c|c|c|}
\hline 168 & 21.6717 & 0.080496 & 0.850478 & 14.921 & 0.247277 \\
\hline 169 & 21.6891 & 0.104559 & 0.582757 & 15.9294 & 0.173036 \\
\hline 170 & 21.6917 & 0.01771 & 0.295788 & 14.1173 & 0.003642 \\
\hline 171 & 21.7055 & 0.064238 & 0.77109 & 13.3768 & 0.220949 \\
\hline 172 & 21.7102 & 0.137783 & 0.77109 & 14.5474 & 0.397597 \\
\hline 173 & 21.7342 & 0.039524 & 0.157464 & 15.9992 & 0.238373 \\
\hline 174 & 21.7473 & 0.169471 & 0.031539 & 14.5824 & 0.414107 \\
\hline 175 & 21.7671 & 0.060291 & 0.031539 & 14.8729 & 0.233001 \\
\hline 176 & 21.776 & 0.30939 & 0.073451 & 17.6636 & 0.685468 \\
\hline 177 & 21.7978 & 0.073338 & 0.541298 & 14.2985 & 0.053726 \\
\hline 178 & 21.809 & 0.273303 & 0.77109 & 13.5815 & 0.212944 \\
\hline 179 & 21.8184 & 0.157507 & 0.295788 & 14.4082 & 0.136389 \\
\hline 180 & 21.825 & 0.33624 & 0.228297 & 15.5965 & 0.109538 \\
\hline 181 & 21.825 & 0.106308 & 0.228297 & 15.6613 & 0.160169 \\
\hline 182 & 21.8299 & 0.16551 & 0.031539 & 14.6252 & 0.170003 \\
\hline 183 & 21.8329 & 0.01075 & 0.157464 & 15.9345 & 0.233111 \\
\hline 184 & 21.8329 & 0.125169 & 0.157464 & 15.9604 & 0.24014 \\
\hline 185 & 21.8409 & 0.120556 & 0.287437 & 16.2518 & 0.501087 \\
\hline 186 & 21.8535 & 0.083951 & 0.591875 & 12.4443 & 0.0743 \\
\hline 187 & 21.8576 & 0.172024 & 0.591875 & 12.4443 & 0.133934 \\
\hline 188 & 21.8764 & 0.38944 & 0.031539 & 16.1831 & 0.781868 \\
\hline 189 & 21.8848 & 0.068251 & 0.850478 & 14.0343 & 0.066133 \\
\hline 190 & 21.8848 & 0.102622 & 0.850478 & 14.1707 & 0.068739 \\
\hline 191 & 21.8877 & 0.520193 & 0.157464 & 16.4824 & 0.157958 \\
\hline 192 & 21.8879 & 0.128654 & 0.582757 & 15.8299 & 0.187031 \\
\hline 193 & 21.8879 & 0.044287 & 0.582757 & 15.9676 & 0.189854 \\
\hline 194 & 21.8919 & 0.182599 & 0.287437 & 16.9458 & 0.215614 \\
\hline 195 & 21.9069 & 0.520193 & 0.620688 & 14.025 & 0.400385 \\
\hline 196 & 21.9143 & 0.358309 & 0.77109 & 13.6794 & 0.279817 \\
\hline 197 & 21.9381 & 0.054453 & 0.031539 & 14.6354 & 0.323556 \\
\hline 198 & 21.9424 & 0.13095 & 0.620688 & 15.0781 & 0.05018 \\
\hline 199 & 21.9623 & 0.127475 & 0.381701 & 17.1257 & 0.781868 \\
\hline 200 & 21.976 & 0.118334 & 0.591875 & 12.4443 & 0.108592 \\
\hline 201 & 21.9872 & 0.035642 & 0.228297 & 15.5603 & 0.172486 \\
\hline 202 & 21.9872 & 0.052887 & 0.228297 & 15.7128 & 0.145648 \\
\hline 203 & 22.0029 & 0.466078 & 0.093681 & 15.7474 & 0.120381 \\
\hline
\end{tabular}


International Journal of Social Science and Economic Research

ISSN: 2455-8834

Volume:06, Issue:03 "March 2021"

\begin{tabular}{|c|c|c|c|c|c|}
\hline 204 & 22.0393 & 0.157508 & 0.157464 & 16.311 & 0.081097 \\
\hline 205 & 22.0409 & 0.100073 & 0.698666 & 16.5057 & 0.36425 \\
\hline 206 & 22.0508 & 0.070743 & 0.591875 & 12.4443 & 0.082336 \\
\hline 207 & 22.0684 & 0.430756 & 0.031539 & 16.6173 & 0.781868 \\
\hline 208 & 22.0995 & 0.049183 & 0.031539 & 17.1634 & 0.781868 \\
\hline 209 & 22.1086 & 0.048128 & 0.031539 & 17.2104 & 0.781868 \\
\hline 210 & 22.1344 & 0.099972 & 0.77109 & 14.2236 & 0.32724 \\
\hline 211 & 22.1344 & 0.237952 & 0.77109 & 13.3622 & 0.276758 \\
\hline 212 & 22.1377 & 0.095449 & 0.850478 & 14.1076 & 0.058913 \\
\hline 213 & 22.1382 & 0.033673 & 0.157464 & 16.3441 & 0.093668 \\
\hline 214 & 22.1587 & 0.067986 & 0.850478 & 13.9913 & 0.067669 \\
\hline 215 & 22.1678 & 0.124231 & 0.77109 & 13.9213 & 0.266047 \\
\hline 216 & 22.1696 & 0.099371 & 0.591875 & 12.4443 & 0.112678 \\
\hline 217 & 22.1702 & 0.332609 & 0.287437 & 16.1691 & 0.420135 \\
\hline 218 & 22.174 & 0.096272 & 0.850478 & 13.9262 & 0.067715 \\
\hline 219 & 22.1916 & 0.155613 & 0.295788 & 14.2619 & 0.134322 \\
\hline 220 & 22.1959 & 0.314591 & 0.093681 & 16.3749 & 0.176837 \\
\hline 221 & 22.2003 & 0.107623 & 0.850478 & 16.765 & 0.396407 \\
\hline 222 & 22.2393 & 0.017145 & 0.698666 & 16.4103 & 0.290881 \\
\hline 223 & 22.2829 & 0.136004 & 0.591875 & 12.4443 & 0.090527 \\
\hline 224 & 22.2833 & 0.141445 & 0.620688 & 14.9551 & 0.063992 \\
\hline 225 & 22.2843 & 0.094455 & 0.698666 & 15.6086 & 0.323522 \\
\hline 226 & 22.3362 & 0.026629 & 0.850478 & 15.1252 & 0.278885 \\
\hline 227 & 22.3379 & 0.01075 & 0.582757 & 15.9243 & 0.200922 \\
\hline 228 & 22.3452 & 0.12355 & 0.591875 & 12.4443 & 0.092758 \\
\hline 229 & 22.3483 & 0.319758 & 0.582757 & 15.9217 & 0.19407 \\
\hline 230 & 22.3617 & 0.291717 & 0.850478 & 12.8937 & 0.030741 \\
\hline 231 & 22.3671 & 0.520193 & 0.287437 & 16.7781 & 0.286223 \\
\hline 232 & 22.3671 & 0.174904 & 0.850478 & 16.9825 & 0.781868 \\
\hline 233 & 22.3671 & 0.10681 & 0.287437 & 16.3661 & 0.446689 \\
\hline 234 & 22.3911 & 0.10366 & 0.591875 & 12.4443 & 0.105043 \\
\hline 235 & 22.4097 & 0.02014 & 0.287437 & 16.2646 & 0.602559 \\
\hline 236 & 22.4526 & 0.27466 & 0.153728 & 15.5836 & 0 \\
\hline 237 & 22.4628 & 0.135394 & 0.295788 & 14.5352 & 0.144181 \\
\hline 238 & 22.5017 & 0.020281 & 0.698666 & 16.5258 & 0.390384 \\
\hline 239 & 22.503 & 0.01075 & 0.698666 & 16.2525 & 0.284724 \\
\hline
\end{tabular}


International Journal of Social Science and Economic Research

ISSN: 2455-8834

Volume:06, Issue:03 "March 2021"

\begin{tabular}{|c|c|c|c|c|c|}
\hline 240 & 22.518 & 0.03066 & 0.287437 & 16.138 & 0.441109 \\
\hline 241 & 22.5222 & 0.01075 & 0.157464 & 16.3406 & 0.094156 \\
\hline 242 & 22.5836 & 0.129976 & 0.093681 & 16.7526 & 0.291106 \\
\hline 243 & 22.5857 & 0.05047 & 0.097367 & 17.7985 & 0.571075 \\
\hline 244 & 22.6005 & 0.062952 & 0.381701 & 17.4296 & 0.781868 \\
\hline 245 & 22.604 & 0.025859 & 0.698666 & 16.3933 & 0.209283 \\
\hline 246 & 22.6149 & 0.149347 & 0.850478 & 16.6628 & 0.386721 \\
\hline 247 & 22.6305 & 0.162527 & 0.097367 & 18.1264 & 0.781868 \\
\hline 248 & 22.6514 & 0.01075 & 0.850478 & 15.9918 & 0.000529 \\
\hline 249 & 22.672 & 0.097693 & 0.850478 & 16.5236 & 0.393364 \\
\hline 250 & 22.6755 & 0.011194 & 0.381701 & 17.3686 & 0.781868 \\
\hline 251 & 22.6971 & 0.017899 & 0.850478 & 16.0095 & 0.000655 \\
\hline 252 & 22.6973 & 0.047545 & 0.287437 & 16.3174 & 0.45066 \\
\hline 253 & 22.7192 & 0.110872 & 0.380092 & 16.1322 & 0.03192 \\
\hline 254 & 22.7368 & 0.245675 & 0.850478 & 16.9847 & 0.385691 \\
\hline 255 & 22.7716 & 0.148295 & 0.381701 & 17.264 & 0.781868 \\
\hline 256 & 22.8076 & 0.081748 & 0.274364 & 12.7212 & 0.222351 \\
\hline 257 & 22.8215 & 0.121905 & 0.698666 & 16.2593 & 0.301281 \\
\hline 258 & 22.8382 & 0.181837 & 0.698666 & 16.4195 & 0.219109 \\
\hline 259 & 22.8562 & 0.23943 & 0.850478 & 17.4541 & 0.781868 \\
\hline 260 & 22.8659 & 0.011053 & 0.274364 & 12.4486 & 0.190625 \\
\hline 261 & 22.8726 & 0.340782 & 0.153728 & 15.8768 & 0 \\
\hline 262 & 22.8797 & 0.284334 & 0.031539 & 16.8675 & 0.781868 \\
\hline 263 & 22.8797 & 0.10203 & 0.031539 & 17.1154 & 0.781868 \\
\hline 264 & 22.8848 & 0.155017 & 0.153728 & 16.2171 & 0.09057 \\
\hline 265 & 22.9181 & 0.118862 & 0.097367 & 18.1264 & 0.781868 \\
\hline 266 & 22.9324 & 0.293011 & 0.850478 & 17.2395 & 0.781868 \\
\hline 267 & 22.9334 & 0.134201 & 0.097367 & 17.8092 & 0.683433 \\
\hline 268 & 22.9403 & 0.275317 & 0.093681 & 16.434 & 0.268014 \\
\hline 269 & 22.9568 & 0.085835 & 0.093681 & 16.8919 & 0.27472 \\
\hline 270 & 22.9912 & 0.161441 & 0.850478 & 17.1344 & 0.38492 \\
\hline 271 & 23.0197 & 0.080589 & 0.456595 & 17.1087 & 0.722248 \\
\hline 272 & 23.041 & 0.520193 & 0.698666 & 16.1443 & 0.269726 \\
\hline 273 & 23.0614 & 0.246524 & 0.850478 & 17.6745 & 0.781868 \\
\hline 274 & 23.0695 & 0.040358 & 0.381701 & 17.3574 & 0.781868 \\
\hline 275 & 23.1156 & 0.346145 & 0.093681 & 16.8095 & 0.287434 \\
\hline
\end{tabular}


International Journal of Social Science and Economic Research

ISSN: 2455-8834

Volume:06, Issue:03 "March 2021"

\begin{tabular}{|c|c|c|c|c|c|}
\hline 276 & 23.1207 & 0.520193 & 0.825346 & 15.9888 & 0.530127 \\
\hline 277 & 23.1524 & 0.457482 & 0.147475 & 16.339 & 0.781868 \\
\hline 278 & 23.1524 & 0.397084 & 0.073451 & 17.394 & 0.651807 \\
\hline 279 & 23.1539 & 0.01075 & 0.850478 & 15.9891 & 0.021133 \\
\hline 280 & 23.1674 & 0.16268 & 0.031539 & 17.0182 & 0.781868 \\
\hline 281 & 23.2114 & 0.164539 & 0.850478 & 17.2867 & 0.378652 \\
\hline 282 & 23.2305 & 0.194603 & 0.097367 & 18.1264 & 0.781868 \\
\hline 283 & 23.2407 & 0.037385 & 0.274364 & 12.6831 & 0.218928 \\
\hline 284 & 23.2454 & 0.055381 & 0.381701 & 17.3179 & 0.781868 \\
\hline 285 & 23.2473 & 0.308809 & 0.825346 & 17.0544 & 0.18385 \\
\hline 286 & 23.2624 & 0.110103 & 0.850478 & 17.5705 & 0.363366 \\
\hline 287 & 23.2845 & 0.031603 & 0.380092 & 15.8458 & 0.037518 \\
\hline 288 & 23.2858 & 0.520193 & 0.456595 & 17.929 & 0.781868 \\
\hline 289 & 23.2887 & 0.216799 & 0.153728 & 16.073 & 0 \\
\hline 290 & 23.2991 & 0.235617 & 0.153728 & 16.4287 & 0 \\
\hline 291 & 23.3117 & 0.520193 & 0.153728 & 16.9482 & 0 \\
\hline 292 & 23.3557 & 0.01075 & 0.380092 & 15.8147 & 0.097065 \\
\hline 293 & 23.3715 & 0.151018 & 0.380092 & 15.9864 & 0.024046 \\
\hline 294 & 23.3904 & 0.090672 & 0.638295 & 18.1264 & 0.505119 \\
\hline 295 & 23.3904 & 0.023047 & 0.638295 & 18.1264 & 0.056267 \\
\hline 296 & 23.4073 & 0.146746 & 0.380092 & 16.3942 & 0.116059 \\
\hline 297 & 23.4075 & 0.137475 & 0.456595 & 17.2375 & 0.75067 \\
\hline 298 & 23.411 & 0.117482 & 0.850478 & 17.3978 & 0.389977 \\
\hline 299 & 23.4123 & 0.133241 & 0.380092 & 16.2573 & 0.024736 \\
\hline 300 & 23.4238 & 0.073003 & 0.097367 & 17.8503 & 0.5906 \\
\hline 301 & 23.465 & 0.079534 & 0.314706 & 18.1264 & 0.737377 \\
\hline 302 & 23.4738 & 0.204923 & 0.825346 & 16.5941 & 0.620864 \\
\hline 303 & 23.48 & 0.07065 & 0.850478 & 17.466 & 0.373068 \\
\hline 304 & 23.5093 & 0.051913 & 0.456595 & 17.0312 & 0.685778 \\
\hline 305 & 23.5463 & 0.080345 & 0.031539 & 15.3848 & 0.018593 \\
\hline 306 & 23.5759 & 0.042342 & 0.850478 & 15.9953 & 0.034086 \\
\hline 307 & 23.5823 & 0.200199 & 0.274364 & 12.4598 & 0.231672 \\
\hline 308 & 23.5874 & 0.042556 & 0.031539 & 15.9809 & 0.001743 \\
\hline 309 & 23.6025 & 0.052878 & 0.749467 & 14.2521 & 0.248806 \\
\hline 310 & 23.6207 & 0.520193 & 0.825346 & 16.4077 & 0.63118 \\
\hline 311 & 23.6291 & 0.520193 & 0.850478 & 15.9538 & 0.042238 \\
\hline
\end{tabular}


International Journal of Social Science and Economic Research

ISSN: 2455-8834

Volume:06, Issue:03 "March 2021"

\begin{tabular}{|c|c|c|c|c|c|}
\hline 312 & 23.6441 & 0.18156 & 0.097367 & 18.1264 & 0.667507 \\
\hline 313 & 23.6521 & 0.33868 & 0.097367 & 18.0902 & 0.565667 \\
\hline 314 & 23.6627 & 0.01075 & 0.638295 & 18.1264 & 0.526275 \\
\hline 315 & 23.6793 & 0.088588 & 0.314706 & 18.1264 & 0.7341 \\
\hline 316 & 23.6857 & 0.2898 & 0.850478 & 17.929 & 0.781868 \\
\hline 317 & 23.6877 & 0.077419 & 0.073451 & 18.1264 & 0.781868 \\
\hline 318 & 23.7019 & 0.081397 & 0.093681 & 16.5123 & 0.275371 \\
\hline 319 & 23.7161 & 0.442847 & 0.380092 & 15.8093 & 0.122236 \\
\hline 320 & 23.7356 & 0.422341 & 0.638295 & 18.1264 & 0.557574 \\
\hline 321 & 23.7488 & 0.128558 & 0.380092 & 16.2566 & 0.023595 \\
\hline 322 & 23.7523 & 0.520193 & 0.825346 & 17.2711 & 0.468215 \\
\hline 323 & 23.773 & 0.012578 & 0.46507 & 13.1407 & 0.438877 \\
\hline 324 & 23.773 & 0.457906 & 0.46507 & 13.5177 & 0.577476 \\
\hline 325 & 23.7982 & 0.164835 & 0.825346 & 17.4237 & 0.246732 \\
\hline 326 & 23.8033 & 0.027024 & 0.46507 & 14.3068 & 0.622099 \\
\hline 327 & 23.8084 & 0.060323 & 0.031539 & 15.9187 & 0.003162 \\
\hline 328 & 23.8108 & 0.231266 & 0.46507 & 14.3342 & 0.628592 \\
\hline 329 & 23.8111 & 0.160951 & 0.380092 & 16.1357 & 0.030681 \\
\hline 330 & 23.8142 & 0.159219 & 0.031539 & 15.6537 & 0.025933 \\
\hline 331 & 23.8161 & 0.270527 & 0.825346 & 16.8335 & 0.651813 \\
\hline 332 & 23.8545 & 0.063945 & 0.228297 & 15.6467 & 0.122176 \\
\hline 333 & 23.8569 & 0.139751 & 0.153728 & 17.6179 & 0 \\
\hline 334 & 23.8997 & 0.520193 & 0.638295 & 18.1264 & 0.659082 \\
\hline 335 & 23.926 & 0.194267 & 0.749467 & 14.5076 & 0.237559 \\
\hline 336 & 23.9465 & 0.520193 & 0.456595 & 16.9806 & 0.695765 \\
\hline 337 & 23.9501 & 0.071525 & 0.073451 & 18.1264 & 0.772331 \\
\hline 338 & 23.9834 & 0.178373 & 0.314706 & 18.1264 & 0.574416 \\
\hline 339 & 23.9905 & 0.128899 & 0.031539 & 15.506 & 0 \\
\hline 340 & 24.0174 & 0.218221 & 0.850478 & 18.1264 & 0.778821 \\
\hline 341 & 24.0191 & 0.132225 & 0.749467 & 14.4577 & 0.269898 \\
\hline 342 & 24.0384 & 0.520193 & 0.46507 & 14.1262 & 0.630756 \\
\hline 343 & 24.0446 & 0.02901 & 0.097367 & 17.7798 & 0.620883 \\
\hline 344 & 24.066 & 0.08354 & 0.314706 & 18.1264 & 0.564891 \\
\hline 345 & 24.0861 & 0.183904 & 0.073451 & 18.1264 & 0.771068 \\
\hline 346 & 24.0902 & 0.105665 & 0.850478 & 18.1264 & 0.752589 \\
\hline 347 & 24.1174 & 0.042756 & 0.638295 & 18.1264 & 0.536396 \\
\hline
\end{tabular}


International Journal of Social Science and Economic Research

ISSN: 2455-8834

Volume:06, Issue:03 "March 2021"

\begin{tabular}{|c|c|c|c|c|c|}
\hline 348 & 24.1886 & 0.03702 & 0.638295 & 18.1264 & 0.38373 \\
\hline 349 & 24.1978 & 0.099416 & 0.850478 & 18.1264 & 0.763474 \\
\hline 350 & 24.229 & 0.520193 & 0.638295 & 16.6546 & 0.781868 \\
\hline 351 & 24.2752 & 0.186989 & 0.031539 & 15.8252 & 0.01839 \\
\hline 352 & 24.3015 & 0.323629 & 0.314706 & 18.1264 & 0.738829 \\
\hline 353 & 24.3071 & 0.031679 & 0.031539 & 16.0244 & 0.016682 \\
\hline 354 & 24.3113 & 0.158995 & 0.850478 & 18.1264 & 0.759634 \\
\hline 355 & 24.3501 & 0.397727 & 0.638295 & 18.1264 & 0.508828 \\
\hline 356 & 24.4334 & 0.135212 & 0.825346 & 16.7819 & 0.514941 \\
\hline 357 & 24.467 & 0.39707 & 0.153728 & 17.4871 & 0 \\
\hline 358 & 24.467 & 0.226881 & 0.153728 & 17.1527 & 0 \\
\hline 359 & 24.5204 & 0.09821 & 0.825346 & 16.9272 & 0.633828 \\
\hline 360 & 24.5381 & 0.09918 & 0.359348 & 15.2579 & 0.148953 \\
\hline 361 & 24.6212 & 0.084888 & 0.749467 & 14.5215 & 0.222045 \\
\hline 362 & 24.6219 & 0.116222 & 0.031539 & 15.9351 & 0.010135 \\
\hline 363 & 24.6268 & 0.059824 & 0.031539 & 15.9932 & 0.00656 \\
\hline 364 & 24.6443 & 0.078812 & 0.359348 & 15.4175 & 0.145513 \\
\hline 365 & 24.7597 & 0.193044 & 0.359348 & 15.6444 & 0.229203 \\
\hline 366 & 24.785 & 0.019254 & 0.359348 & 15.1882 & 0.116846 \\
\hline 367 & 24.7863 & 0.520193 & 0.073451 & 18.0984 & 0.704078 \\
\hline 368 & 24.8092 & 0.118482 & 0.749467 & 14.7837 & 0.258036 \\
\hline 369 & 24.8746 & 0.01075 & 0.359348 & 15.3483 & 0.134489 \\
\hline 370 & 24.9028 & 0.157087 & 0.359348 & 15.5854 & 0.15022 \\
\hline 371 & 24.9302 & 0.268333 & 0.359348 & 15.4576 & 0.143392 \\
\hline 372 & 24.9409 & 0.048807 & 0.359348 & 15.2544 & 0.163145 \\
\hline 373 & 25.054 & 0.258871 & 0.749467 & 15.0366 & 0.301909 \\
\hline 374 & 25.0569 & 0.027701 & 0.359348 & 15.523 & 0.148953 \\
\hline 375 & 25.0864 & 0.091221 & 0.749467 & 14.9872 & 0.26715 \\
\hline 376 & 25.2231 & 0.084841 & 0.749467 & 14.8952 & 0.265901 \\
\hline 377 & 25.233 & 0.254407 & 0.749467 & 15.0266 & 0.221531 \\
\hline 378 & 25.233 & 0.064938 & 0.248782 & 14.7962 & 0.10616 \\
\hline 379 & 25.233 & 0.13841 & 0.736892 & 17.8395 & 0.08538 \\
\hline 380 & 25.233 & 0.057022 & 0.736892 & 18.1264 & 0.144774 \\
\hline 381 & 25.233 & 0.056515 & 0.248782 & 14.8176 & 0.102655 \\
\hline 382 & 25.233 & 0.134225 & 0.736892 & 18.1264 & 0.154043 \\
\hline 383 & 25.233 & 0.281756 & 0.248782 & 15.7972 & 0.213318 \\
\hline
\end{tabular}


International Journal of Social Science and Economic Research

ISSN: 2455-8834

Volume:06, Issue:03 "March 2021"

\begin{tabular}{|c|c|c|c|c|c|}
384 & 25.233 & 0.056149 & 0.248782 & 16.9676 & 0.728482 \\
\hline 385 & 25.233 & 0.184775 & 0.248782 & 17.3027 & 0.731704 \\
\hline 386 & 25.233 & 0.257131 & 0.736892 & 18.0683 & 0.113879 \\
\hline 387 & 25.233 & 0.186518 & 0.248782 & 17.1712 & 0.682373 \\
\hline 388 & 25.233 & 0.137936 & 0.248782 & 17.0852 & 0.742952 \\
\hline 389 & 25.233 & 0.094696 & 0.736892 & 18.1264 & 0.13006 \\
\hline 390 & 25.233 & 0.10224 & 0.248782 & 16.9471 & 0.607454 \\
\hline 391 & 25.233 & 0.030745 & 0.248782 & 16.9732 & 0.755779 \\
\hline 392 & 25.233 & 0.135503 & 0.736892 & 18.1264 & 0.004684 \\
\hline 393 & 25.233 & 0.011009 & 0.736892 & 18.1264 & 0.004633 \\
\hline 394 & 25.233 & 0.102137 & 0.736892 & 18.1264 & 0 \\
\hline 395 & 25.233 & 0.079235 & 0.736892 & 18.1264 & 0 \\
\hline 396 & 25.3592 & 0.09516948 & 0.74057646 & 18.217032 & 0.1307103 \\
\hline 397 & 25.3592 & 0.1027512 & 0.25002591 & 17.0318355 & 0.61049127 \\
\hline 398 & 25.3592 & 0.030898725 & 0.25002591 & 17.058066 & 0.759557895 \\
\hline 399 & 25.3592 & 0.136180515 & 0.74057646 & 18.217032 & 0.00470742 \\
\hline 400 & 25.3592 & 0.011064045 & 0.74057646 & 18.217032 & 0.004656165 \\
\hline
\end{tabular}

